\title{
Taxonomic, ecological and morphological diversity of Ponto-Caspian gammaridean amphipods: a review
}

\author{
Denis Copilaș-Ciocianu ${ }^{1} *$ (ORCID: 0000-0002-6374-2365), Dmitry Sidorov ${ }^{2}$ (ORCID: 0000-0003-2635-9129) \\ ${ }^{1}$ Laboratory of Evolutionary Ecology of Hydrobionts, Nature Research Centre, Vilnius, Lithuania; ${ }^{2}$ Federal Scientific Centre \\ of the East Asia Terrestrial Biodiversity, Far Eastern Branch of the Russian Academy of Sciences, Vladivostok, Russian \\ Federation \\ *Corresponding author: denis.copilas-ciocianu@gamtc.It
}

\begin{abstract}
Thanks to its dynamic geological history the Ponto-Caspian region harbors a unique and unusually adaptable fauna, notorious for its invasive species. Gammarid amphipods attained considerable diversity, becoming the world's second most speciose ancient-lake amphipod radiation. Nonetheless, apart from a few invasive species, this group remains poorly studied. Herein, we review and quantify the taxonomic, morphological and ecological diversity, as well as phylogenetic context of Ponto-Caspian gammarids within the adaptive radiation framework. Published molecular phylogenies indicate that this radiation has a monophyletic mid-Miocene Paratethyan origin, and is nested within the morphologically-conserved Atlanto-Mediterranean genus Echinogammarus. We find extensive disparity in body shape, size, ornamentation and appendage length, along a broad ecological gradient from mountain springs to depths exceeding $500 \mathrm{~m}$, on virtually all substrate types (including symbiosis). We propose four putative ecomorphs that appear convergent with distantly related oceanic and Baikal Lake taxa. Thus, the identified patterns support the adaptive radiation model, although extensive further research is needed. A checklist and provisional key to all known endemic species are provided to facilitate taxonomic research. Ponto-Caspian gammarids could be a potentially powerful model for studying adaptive radiations and invasive species evolution.
\end{abstract}

Keywords: ancient lake, crustacean, evolution, radiation, systematics

Acknowledgements This study was financed by the Lithuanian Research Council (contract no. 09.3.3LMT-K-712-19-0149). We thank Nadezhda Berezina for providing important literature.

\section{Introduction}

Ancient lakes are evolutionary cradles, harboring a rich endemic fauna that fascinated biologists for centuries (M. E. Cristescu et al. 2010; Martens 1997). Their confined nature coupled with large size and relative stability over geological time scales promoted lineage accumulation, diversification and ecological specialization. Many of these lineages probably arose through adaptive radiation, an evolutionary process wherein species rapidly evolve from a common ancestor and diversify to occupy various ecological niches (Schluter 2000). Classical examples of adaptive radiations in ancient lakes are cichlid species flocks in African Rift Valley lakes (Salzburger et al. 2014), or the gammarid amphipods inhabiting Lake Baikal (Naumenko et al. 2017).

Situated in the Ponto-Caspian region, the Caspian Sea is the world's largest ancient lake (M. E. Cristescu et al. 2010). The Azov, Aral and Black seas are also part of this system. These water bodies are remnants of the once widespread epicontinental Paratethys Sea, which stretched from the foothills of the Alps to the Himalayas (Popov et al. 2004). The Paratethys had a turbulent geological history with numerous regression-transgression phases causing drastic salinity fluctuations and repeated episodes of isolation and reconnection with the world ocean (Audzijonyte et al. 2015; Palcu et al. 2019; Popov et al. 2004; Rögl 1999). The uplift of the Caucasus range during the late Miocene triggered the formation and separation of the Black and Caspian seas. During the last two million 
years these two basins experienced recurrent phases of mutual isolation and reconnection (Krijgsman et al. 2019).

It is thought that this tumultuous geological past drove the evolution of the unusually euryhaline fauna that inhabits the region today (Reid and Orlova 2002). This plasticity has enabled many PontoCaspian species to spread across the Northern Hemisphere and become invasive due to human interference (Adrian-Kalchhauser et al. 2020; Cuthbert et al. 2020; Vanderploeg et al. 2002). Nevertheless, many Ponto-Caspian endemics face severe conservation challenges due to climate change, invasive species and multifarious anthropogenic disturbances (Dumont 1995; Gogaladze et al. 2020; Lattuada et al. 2019; Prange et al. 2020). The Ponto-Caspian region is a hot-spot of endemicity and biodiversity with hundreds of species from various animal phyla, but particularly rich in crustaceans (Birstein et al. 1968; Chertoprud et al. 2018; M. E. A. Cristescu and Hebert 2005; Mordukhai-Boltovskoi 1979; Naseka and Bogutskaya 2009; Wesselingh et al. 2019).

Amphipod crustaceans radiated multiple times in the world's temperate ancient lakes. Several radiations occurred in Lake Titicaca (Hyalellidae) (Adamowicz et al. 2018; Jurado-Rivera et al. 2020), two in Lake Baikal (Gammaridae) (Macdonald et al. 2005; Naumenko et al. 2017), probably two in the Ponto-Caspian basin (Gammaroidea, Corophiidae) (M. E. A. Cristescu and Hebert 2005; Hou et al. 2014), and apparently one radiation in other lakes such as Ohrid (Gammaridae) (Wysocka et al. 2013, 2014), and Fuxian Hu (Anisogammaridae) (Sket and Fišer 2009). Other lakes throughout Asia also harbor endemic species, although their monophyly has yet to be proven. These are Lake Issyk-Kul in Kyrgyzstan (Gammaridae) (Karaman and Pinkster 1977) and Lake Teletskoye (Gammaridae) in Russia (Martynov 1930). In most of these lakes amphipods display a bewildering diversity in form and ecology, with remarkable convergence in body armature among evolutionary and geographically distant groups (Martens 1997).

The endemic amphipod fauna of the Ponto-Caspian basin is one of the world's most diverse, second only to Lake Baikal (Barnard and Barnard 1983; Väinölä et al. 2008). Among all endemic PontoCaspian organisms, amphipods seem to be the most species-rich and successful group, attaining significant ecological and morphological disparity, akin to an adaptive radiation (Derzhavin 1948; Pjatakova and Tarasov 1996; Sars 1895). However, despite these appealing features for evolutionary and ecological studies, Ponto-Caspian amphipods are obscure and poorly known, even ignored in some relatively recent reviews (Martens and Schön 1999). Most attention has been focused on the invasive species that are spreading throughout European freshwaters (e.g. Cristescu et al., 2004; Grabowski et al., 2007; Arbačiauskas et al., 2013; Rewicz et al., 2015), while the non-invasive ones were largely ignored in the last two decades. The taxonomy of the group is rather chaotic due to old and incomplete species descriptions, which led to fuzzy generic diagnoses and lack of a formal system. Even online databases such as World Amphipoda Database (http://www.marinespecies.org/amphipoda/) are incomplete (Horton et al. 2020). Furthermore, a significant part of the literature predates the digital era and is published in Russian, thus not readily available for the international community. As such, to date, there is no comprehensive overview of the Ponto-Caspian amphipod diversity in terms of taxa, ecology and morphology. Some attempts have been made in the past, but these either focused on taxonomy or ecology and never considered the amphipods from all of the Ponto-Caspian basins (Birstein and Romanova 1968; MordukhaiBoltovskoi 1964, 1979; Pjatakova and Tarasov 1996).

In this study we aim to provide a first comprehensive overview of endemic Ponto-Caspian gammaridean amphipods (taxonomy, morphology and ecology) by examining all of the original species descriptions and relevant literature. Furthermore, by integrating the results of this study with previous phylogenetic research, we strived to identify to which extent the current knowledge on Ponto-Caspian amphipods satisfies the adaptive radiation model (Schluter 2000; Simões et al. 2016). 
102 Specifically, we looked for evidence pointing to: I) monophyly of endemic Ponto-Caspian gammarids, II) an increase in their diversification rates, and III) ecomorphological divergence.

This overview is intended to serve as a foundation and to encourage future eco-evolutionary and taxonomic studies on Ponto-Caspian amphipods. To this end, we also provide a complete checklist and a provisional key to all known endemic species in the hopes of reviving taxonomic interest and to stabilize the systematics of the group.

\section{Taxonomic diversity}

Our study focuses on the Ponto-Caspian amphipod taxa that belong to the superfamily Gammaroidea. Specifically, we included the endemic genera of the family Gammaridae, as well as the fully endemic families Behningiellidae, Caspicolidae, Iphigenellidae, and Pontogammaridae. These taxa form the bulk of the endemic diversity and are most likely a monophyletic group (Hou et al. 2014; Sket and Hou 2018), which is a necessary prerequisite for the adaptive radiation model (Schluter 2000). The remaining Ponto-Caspian endemic amphipods such as Chelicorophium (9 spp., Corophiidae), Gammaracanthus (1 sp., Gammaracanthidae), Niphargus (1 sp.), Onisimus (2 spp., Uristidae), and Monoporeia (1 sp.) were excluded since they are unrelated to the focal gammarids (Copilaş-Ciocianu et al. 2020; Lowry and Myers 2017; Väinölä et al. 2001). However, we include the monotypic family Caspicolidae because it is very likely a highly derived gammarid (Derzhavin 1944). Although this family is currently included in the infraorder Talitridira by Lowry \& Myers (2013), we consider this placement erroneous due to a character coding mistake (see Discussion for further details).

We compiled a checklist of all known Ponto-Caspian gammaroids by reviewing all of the original species descriptions, including re-descriptions. It is presented in Table 1 along with species systematics, native distribution and short taxonomic remarks where necessary. A total of 82 valid extant species are known, belonging to 34 genera and five families: Behningiellidae ( 3 genera, 4 spp.), Caspicolidae (monotypic), Gammaridae (18 genera, 39 spp.), Iphigenellidae (monotypic) and Pontogammaridae (11 genera, 37 spp.) (Fig. 1a). Five species are doubtful since they may be junior synonyms and further study is needed (Table 1). The most diverse genus is Pontogammarus ( $8 \mathrm{spp}$. ), followed by Dikerogammarus and Obesogammarus (7 spp. each), Stenogammarus (6 spp.), Chaetogammarus and Amathillina (5 spp. each). Eighteen genera (53\%) are monotypic (Fig. 1a). The extinct fossil genera Andrussovia ( 3 spp.) and Praegmelina ( 2 spp.) are currently placed in the Pontogammaridae (Table 1).

The trend of species description through time reveals little taxonomic activity from the $18^{\text {th }}$ to late $19^{\text {th }}$ centuries, a sudden increase with Sars' monographs in the late $19^{\text {th }}$ century, followed by a more or less steady increase towards the present day with peaks of activity in the middle $20^{\text {th }}$ century by Russian and Romanian authors (Fig. 1b). A noticeable stagnation can be observed in the last two decades. By far the most prolific author was G. O. Sars (37 spp.), followed by A. N. Derzhavin (9 spp.) and S. Cărăușu (8 spp.)(Fig. 1b inset).

A provisional key to all known endemic families, genera and species (including non-Gammaroidea) is provided in the Appendix. We emphasize that some taxa are poorly known and have an uncertain generic placement. 
bioRxiv preprint doi: https://doi.org/10.1101/2021.01.21.427559; this version posted January 21, 2021. The copyright holder for this preprint (which was not certified by peer review) is the author/funder, who has granted bioRxiv a license to display the preprint in perpetuity. It is made available under aCC-BY-NC-ND 4.0 International license.

152

153

154

Table 1. Checklist, taxonomy and native distribution of extant and fossil Ponto-Caspian gammaroid amphipods.

\begin{tabular}{|c|c|c|c|c|c|}
\hline Family & Species & Authority & $\begin{array}{l}\text { Distribution } \\
\text { basin }\end{array}$ & Status & Taxonomic remarks \\
\hline Behningiellidae & Behningiella brachypus & Derzhavin, 1948 & Caspian & valid & \\
\hline Behningiellidae & Cardiophilus baeri & G.O. Sars, 1896 & Caspian & valid & \\
\hline Behningiellidae & Cardiophilus marisnigrae & Miloslavskaja, 1931 & Ponto-Azov & valid & $\begin{array}{l}\text { Original spelling: C. maris- } \\
\text { nigirs } \\
\text { Emended by Barnard (1958) } \\
\text { according to ICZN article } \\
\text { 32.5.2.3 } \\
\text { Synonyms: Cardiophilus } \\
\text { miloslavskajae Cărăușu, } 1955\end{array}$ \\
\hline Behningiellidae & Zernovia volgensis & Derzhavin, 1948 & Caspian & valid & \\
\hline Caspicolidae & Caspicola knipovitschi & Derzhavin, 1944 & Caspian & valid & \\
\hline Gammaridae & $\begin{array}{l}\text { Akerogammarus } \\
\text { contiguus }\end{array}$ & (Pjatakova, 1962) & Caspian & valid & \\
\hline Gammaridae & $\begin{array}{l}\text { Akerogammarus } \\
\text { knipowitschi }\end{array}$ & $\begin{array}{l}\text { Derzhavin \& } \\
\text { Pjatakova, } 1967\end{array}$ & Caspian & valid & \\
\hline Gammaridae & Amathillina affinis & G.O. Sars, 1894 & Caspian & valid & \\
\hline Gammaridae & Amathillina cristata & G.O. Sars, 1894 & $\begin{array}{l}\text { Caspian, } \\
\text { Ponto-Azov }\end{array}$ & valid & \\
\hline Gammaridae & Amathillina maximowiczi & G.O. Sars, 1896 & Caspian & valid & \\
\hline Gammaridae & Amathillina pusilla & G.O. Sars, 1896 & Caspian & valid & \\
\hline Gammaridae & Amathillina spinosa & G.O. Sars, 1896 & Caspian & valid & \\
\hline Gammaridae & Axelboeckia spinosa & (G.O. Sars, 1894) & Caspian & valid & \\
\hline Gammaridae & Baku paradoxus & $\begin{array}{l}\text { (Derzhavin in } \\
\text { Derzhavin \& } \\
\text { Pjatakova, 1967) } \\
\end{array}$ & Caspian & valid & \\
\hline Gammaridae & $\begin{array}{l}\text { Cephalogammarus } \\
\text { macrocephalus }\end{array}$ & (G.O. Sars, 1896) & Caspian & valid & $\begin{array}{l}\text { Possibly a derived } \\
\text { Dikerogammarus }\end{array}$ \\
\hline Gammaridae & $\begin{array}{l}\text { Chaetogammarus } \\
\text { hyrcanus }\end{array}$ & Pjatakova, 1962 & Caspian & valid & \\
\hline Gammaridae & $\begin{array}{l}\text { Chaetogammarus } \\
\text { ischnus }\end{array}$ & (Stebbing, 1899) & $\begin{array}{l}\text { Caspian, } \\
\text { Ponto-Azov }\end{array}$ & valid & $\begin{array}{l}\text { Nom. nov. for Gammarus } \\
\text { tennelus Sars 1896; } \\
\text { Synonyms: Gammarus } \\
\text { sowinskyi (Behning, 1914) }\end{array}$ \\
\hline Gammaridae & $\begin{array}{l}\text { Chaetogammarus } \\
\text { pauxillus }\end{array}$ & (G.O. Sars, 1896) & Caspian & valid & \\
\hline Gammaridae & $\begin{array}{l}\text { Chaetogammarus } \\
\text { placidus }\end{array}$ & (G.O. Sars, 1896) & $\begin{array}{l}\text { Caspian, } \\
\text { Ponto-Azov }\end{array}$ & valid & \\
\hline Gammaridae & $\begin{array}{l}\text { Chaetogammarus } \\
\text { warpachowskyi }\end{array}$ & (G.O. Sars, 1894) & $\begin{array}{l}\text { Caspian, } \\
\text { Ponto-Azov }\end{array}$ & valid & $\begin{array}{l}\text { Reassessment of generic } \\
\text { status needed. Close } \\
\text { morphological affinities with } \\
\text { Gmelina group. }\end{array}$ \\
\hline Gammaridae & Derzhavinella cava & $\begin{array}{l}\text { Stock, Mirzajani, } \\
\text { Vonk, Naderi, Kiabi, } \\
1998\end{array}$ & Caspian & valid & \\
\hline Gammaridae & $\begin{array}{l}\text { Derzhavinella } \\
\text { macrochelata }\end{array}$ & Birstein, 1938 & Caspian & valid & \\
\hline Gammaridae & $\begin{array}{l}\text { Dikerogammarus } \\
\text { aralychensis }\end{array}$ & (Birstein, 1932) & Caucasus & doubtful & $\begin{array}{l}\text { Probably junior synonym of } \\
\text { Pontogammarus setosus } \\
\text { (Schäferna, 1914). Further } \\
\text { research needed. }\end{array}$ \\
\hline Gammaridae & $\begin{array}{l}\text { Dikerogammarus } \\
\text { bispinosus }\end{array}$ & Martynov, 1925 & $\begin{array}{l}\text { Caspian, } \\
\text { Ponto-Azov }\end{array}$ & valid & \\
\hline Gammaridae & Dikerogammarus caspius & (Pallas, 1771) & Caspian & valid & \\
\hline Gammaridae & $\begin{array}{l}\text { Dikerogammarus } \\
\text { fluviatilis }\end{array}$ & Martynov, 1919 & $\begin{array}{l}\text { Caspian, } \\
\text { Ponto-Azov }\end{array}$ & doubtful & $\begin{array}{l}\text { Initially described by } \\
\text { Martynov } 1919 \text { as a morph of } \\
\text { D. haemobaphes. Further }\end{array}$ \\
\hline
\end{tabular}


bioRxiv preprint doi: https://doi.org/10.1101/2021.01.21.427559; this version posted January 21, 2021. The copyright holder for this preprint (which was not certified by peer review) is the author/funder, who has granted bioRxiv a license to display the preprint in perpetuity. It is made available under aCC-BY-NC-ND 4.0 International license.

\begin{tabular}{|c|c|c|c|c|c|}
\hline & & & & & research needed. \\
\hline Gammaridae & Dikerogammarus gruberi & $\begin{array}{l}\text { Mateus \& Mateus, } \\
1990\end{array}$ & Ponto-Azov & valid & \\
\hline Gammaridae & $\begin{array}{l}\text { Dikerogammarus } \\
\text { haemobaphes }\end{array}$ & (Eichwald, 1841) & $\begin{array}{l}\text { Caspian, } \\
\text { Ponto-Azov }\end{array}$ & valid & $\begin{array}{l}\text { Synonym: Dikerogammarus } \\
\text { balatonicus Pony, } 1958\end{array}$ \\
\hline Gammaridae & $\begin{array}{l}\text { Dikerogammarus } \\
\text { istanbulensis }\end{array}$ & $\begin{array}{l}\text { Özbek and Özkan, } \\
2011\end{array}$ & Ponto-Azov & valid & \\
\hline Gammaridae & Dikerogammarus oskari & Birstein, 1945 & Caspian & valid & $\begin{array}{l}\text { Nom. nov. for Gammarus } \\
\text { grimmi Sars } 1896\end{array}$ \\
\hline Gammaridae & Dikerogammarus villosus & (Sowinsky, 1894) & $\begin{array}{l}\text { Caspian, } \\
\text { Ponto-Azov }\end{array}$ & valid & \\
\hline Gammaridae & Gmelina aestuarica & Cărăușu, 1943 & Ponto-Azov & valid & \\
\hline Gammaridae & Gmelina costata & G.O. Sars, 1894 & $\begin{array}{l}\text { Caspian, } \\
\text { Ponto-Azov }\end{array}$ & valid & \\
\hline Gammaridae & Gmelinopsis aurita & G.O. Sars, 1896 & Caspian & valid & \\
\hline Gammaridae & Gmelinopsis tuberculata & G.O. Sars, 1896 & $\begin{array}{l}\text { Caspian, } \\
\text { Ponto-Azov }\end{array}$ & valid & \\
\hline Gammaridae & Kuzmelina kusnezowi & (Sowinsky, 1894) & $\begin{array}{l}\text { Caspian, } \\
\text { Ponto-Azov }\end{array}$ & valid & \\
\hline Gammaridae & Jugogammarus kusceri & (S. Karaman, 1931) & Balkan & valid & \\
\hline Gammaridae & $\begin{array}{l}\text { Lanceogammarus } \\
\text { andrussowi }\end{array}$ & (G.O. Sars, 1896) & $\begin{array}{l}\text { Caspian, } \\
\text { Ponto-Azov }\end{array}$ & valid & \\
\hline Gammaridae & Scytaelina simplex & $\begin{array}{l}\text { Stock, Mirzajani, } \\
\text { Vonk, Naderi, Kiabi, } \\
1998\end{array}$ & Caspian & valid & \\
\hline Gammaridae & $\begin{array}{l}\text { Shablogammarus } \\
\text { shablensis }\end{array}$ & (Cărăușu, 1943) & $\begin{array}{l}\text { Caspian, } \\
\text { Ponto-Azov }\end{array}$ & valid & $\begin{array}{l}\text { Original spelling: Gammarus } \\
\text { chablensis } \\
\text { Emended by Cărăuşu et al. } \\
(1955)\end{array}$ \\
\hline Gammaridae & Sowinskya macrocera & Derzhavin, 1948 & Caspian & Valid & \\
\hline Gammaridae & $\begin{array}{l}\text { Trichogammarus } \\
\text { trichiatus }\end{array}$ & (Martynov, 1932) & Ponto-Azov & Valid & $\begin{array}{l}\text { We do not agree that } \\
\text { Chaetogammarus tennelus } \\
\text { major Cărăușu, } 1943 \text { is a } \\
\text { junior synonym. Further } \\
\text { study is needed. }\end{array}$ \\
\hline Gammaridae & Yogmelina brachyura & $\begin{array}{l}\text { (Derzhavin \& } \\
\text { Pjatakova, 1962) }\end{array}$ & Caspian & valid & \\
\hline Gammaridae & Yogmelina laeviuscula & (G.O. Sars, 1896) & Caspian & valid & \\
\hline Gammaridae & Yogmelina limana & $\begin{array}{l}\text { G.S. Karaman \& } \\
\text { Barnard, } 1979 \\
\end{array}$ & Ponto-Azov & valid & \\
\hline Gammaridae & Yogmelina ovata & (Martynov, 1924) & Ponto-Azov & doubtful & $\begin{array}{l}\text { Probably junior synonym of } \\
\text { Chaetogammarus } \\
\text { warpachowskyi. Further } \\
\text { study is needed. }\end{array}$ \\
\hline Gammaridae & Yogmelina pusilla & (G.O. Sars, 1896) & $\begin{array}{l}\text { Caspian, } \\
\text { ?Ponto-Azov }\end{array}$ & valid & \\
\hline Iphigenellidae & Iphigenella acanthopoda & G.O. Sars, 1896 & $\begin{array}{l}\text { Caspian, } \\
\text { Ponto-Azov }\end{array}$ & valid & \\
\hline Pontogammaridae & $\begin{array}{l}\text { Compactogammarus } \\
\text { compactus }\end{array}$ & (G.O. Sars, 1895) & $\begin{array}{l}\text { Caspian, } \\
\text { Ponto-Azov }\end{array}$ & valid & \\
\hline Pontogammaridae & $\begin{array}{l}\text { Niphargogammarus } \\
\text { aequimanus }\end{array}$ & (G.O. Sars, 1895) & Caspian & valid & \\
\hline Pontogammaridae & $\begin{array}{l}\text { Niphargogammarus } \\
\text { borodini }\end{array}$ & (G.O. Sars, 1897) & Caspian & valid & \\
\hline Pontogammaridae & $\begin{array}{l}\text { Niphargogammarus } \\
\text { intermedius }\end{array}$ & (Cărăușu, 1943) & Ponto-Azov & valid & \\
\hline Pontogammaridae & $\begin{array}{l}\text { Niphargogammarus } \\
\text { quadrimanus }\end{array}$ & (G.O. Sars, 1895) & Caspian & valid & \\
\hline Pontogammaridae & Niphargoides boltovskoyi & $\begin{array}{l}\text { Derzhavin \& } \\
\text { Pjatakova, } 1968\end{array}$ & Caspian & valid & \\
\hline Pontogammaridae & Niphargoides caspius & G.O. Sars, 1894 & Caspian & valid & \\
\hline Pontogammaridae & Niphargoides & G.O. Sars, 1894 & Caspian, & valid & \\
\hline
\end{tabular}


bioRxiv preprint doi: https://doi.org/10.1101/2021.01.21.427559; this version posted January 21, 2021. The copyright holder for this preprint (which was not certified by peer review) is the author/funder, who has granted bioRxiv a license to display the preprint in perpetuity. It is made available under aCC-BY-NC-ND 4.0 International license.

\begin{tabular}{|c|c|c|c|c|c|}
\hline & corpulentus & & Ponto-Azov & & \\
\hline Pontogammaridae & Niphargoides grimmi & G.O. Sars, 1896 & Caspian & valid & \\
\hline Pontogammaridae & $\begin{array}{l}\text { Obesogammarus } \\
\text { acuminatus }\end{array}$ & $\begin{array}{l}\text { Stock, Mirzajani, } \\
\text { Vonk, Naderi, Kiabi, } \\
1998\end{array}$ & Caspian & valid & \\
\hline Pontogammaridae & $\begin{array}{l}\text { Obesogammarus } \\
\text { boeoticus }\end{array}$ & $\begin{array}{l}\text { (Schellenberg, } \\
\text { 1944) }\end{array}$ & Balkan & valid & $\begin{array}{l}\text { Poorly described, generic } \\
\text { status needs revision }\end{array}$ \\
\hline Pontogammaridae & Obesogammarus crassus & (G.O. Sars, 1894) & $\begin{array}{l}\text { Caspian, } \\
\text { Ponto-Azov }\end{array}$ & valid & $\begin{array}{l}\text { Synonyms: Obesogammarus } \\
\text { crassus f. mediodanubialis S. } \\
\text { Karaman, } 1953\end{array}$ \\
\hline Pontogammaridae & Obesogammarus obesus & (G.O. Sars, 1894) & $\begin{array}{l}\text { Caspian, } \\
\text { Ponto-Azov }\end{array}$ & valid & \\
\hline Pontogammaridae & $\begin{array}{l}\text { Obesogammarus } \\
\text { olvianus }\end{array}$ & (Sowinsky, 1902) & $\begin{array}{l}\text { Caspian, } \\
\text { Ponto-Azov }\end{array}$ & valid & \\
\hline Pontogammaridae & $\begin{array}{l}\text { Obesogammarus } \\
\text { platycheir }\end{array}$ & (G.O. Sars, 1896) & Caspian & valid & \\
\hline Pontogammaridae & $\begin{array}{l}\text { Obesogammarus } \\
\text { subnudus }\end{array}$ & (G.O. Sars, 1896) & $\begin{array}{l}\text { Caspian, } \\
\text { Ponto-Azov }\end{array}$ & valid & $\begin{array}{l}\text { Provisionally placed in } \\
\text { Obesogammarus. Generic } \\
\text { status needs revision. }\end{array}$ \\
\hline Pontogammaridae & Pandorites podoceroides & (G.O. Sars, 1896) & Caspian & valid & \\
\hline Pontogammaridae & $\begin{array}{l}\text { Paraniphargoides } \\
\text { derzhavini }\end{array}$ & Pjatakova, 1962 & Caspian & valid & \\
\hline Pontogammaridae & Paraniphargoides motasi & (Cărăușu, 1943) & $\begin{array}{l}\text { Caspian, } \\
\text { Ponto-Azov }\end{array}$ & valid & \\
\hline Pontogammaridae & $\begin{array}{l}\text { Pontogammarus } \\
\text { abbreviatus }\end{array}$ & (G.O. Sars, 1894) & $\begin{array}{l}\text { Caspian, } \\
\text { Ponto-Azov }\end{array}$ & valid & \\
\hline Pontogammaridae & $\begin{array}{l}\text { Pontogammarus } \\
\text { aestuarius }\end{array}$ & (G.O. Sars, 1894) & $\begin{array}{l}\text { Caspian, } \\
\text { Ponto-Azov }\end{array}$ & valid & \\
\hline Pontogammaridae & Pontogammarus borceae & Carausu, 1943 & $\begin{array}{l}\text { Caspian, } \\
\text { Ponto-Azov }\end{array}$ & valid & \\
\hline Pontogammaridae & $\begin{array}{l}\text { Pontogammarus } \\
\text { palmatus }\end{array}$ & (Martynov, 1925) & Caspian & doubtful & $\begin{array}{l}\text { Poor description without } \\
\text { illustrations. }\end{array}$ \\
\hline Pontogammaridae & $\begin{array}{l}\text { Pontogammarus } \\
\text { robustoides }\end{array}$ & (G.O. Sars, 1894) & $\begin{array}{l}\text { Caspian, } \\
\text { Ponto-Azov }\end{array}$ & valid & \\
\hline Pontogammaridae & Pontogammarus setosus & (Schäferna, 1914) & Caucasus & valid & \\
\hline Pontogammaridae & $\begin{array}{l}\text { Pontogammarus } \\
\text { (=Euxinia) maeoticus }\end{array}$ & (Sowinsky, 1894) & $\begin{array}{l}\text { Caspian, } \\
\text { Ponto-Azov }\end{array}$ & valid & $\begin{array}{l}\text { Removed to Pontogammarus } \\
\text { since Euxinia Tucolesco, } 1933 \\
\text { is preoccupied by the } \\
\text { platyhelminth genus Euxinia } \\
\text { Graff, } 1911 \text {. According to } \\
\text { ICZN articles } 23.1 \text { and } 52.4 \\
\text { Synonyms: Euxinia fagei } \\
\text { Tucolesco, } 1933\end{array}$ \\
\hline Pontogammaridae & $\begin{array}{l}\text { Pontogammarus } \\
\text { (=Euxinia) sarsi }\end{array}$ & (Sowinsky, 1898) & $\begin{array}{l}\text { Caspian, } \\
\text { Ponto-Azov }\end{array}$ & valid & $\begin{array}{l}\text { Removed to Pontogammarus } \\
\text { since Euxinia Tucolesco, } 1933 \\
\text { is preoccupied by the } \\
\text { platyhelminth genus Euxinia } \\
\text { Graff, } 1911 \text {. According to } \\
\text { ICZN articles } 23.1 \text { and } 52.4\end{array}$ \\
\hline Pontogammaridae & $\begin{array}{l}\text { Pontogammarus } \\
\text { (=Euxinia) weidemanni }\end{array}$ & (G.O. Sars, 1896) & $\begin{array}{l}\text { Caspian, } \\
\text { Ponto-Azov }\end{array}$ & valid & $\begin{array}{l}\text { Removed to Pontogammarus } \\
\text { since Euxinia Tucolesco, } 1933 \\
\text { is preoccupied by the } \\
\text { platyhelminth genus Euxinia } \\
\text { Graff, } 1911 \text {. According to } \\
\text { ICZN articles } 23.1 \text { and } 52.4\end{array}$ \\
\hline Pontogammaridae & $\begin{array}{l}\text { Stenogammarus } \\
\text { compressus }\end{array}$ & (G.O. Sars, 1894) & $\begin{array}{l}\text { Caspian, } \\
\text { Ponto-Azov }\end{array}$ & valid & \\
\hline Pontogammaridae & $\begin{array}{l}\text { Stenogammarus } \\
\text { compressosimilis }\end{array}$ & Cărăușu 1955 & $\begin{array}{l}\text { Caspian, } \\
\text { Ponto-Azov }\end{array}$ & valid & $\begin{array}{l}\text { Original spelling: } S \text {. } \\
\text { compresso-similis } \\
\text { Emended according to ICZN } \\
\text { article } 32.5 .2 .3 \\
\text { Synonyms: Stenogammarus }\end{array}$ \\
\hline
\end{tabular}


bioRxiv preprint doi: https://doi.org/10.1101/2021.01.21.427559; this version posted January 21, 2021. The copyright holder for this preprint (which was not certified by peer review) is the author/funder, who has granted bioRxiv a license to display the preprint in perpetuity. It is made available under aCC-BY-NC-ND 4.0 International license.

\begin{tabular}{|c|c|c|c|c|c|}
\hline & & & & & $\begin{array}{l}\text { kereuschi Derzhavin \& } \\
\text { Pjatakova, } 1962 \text { according to } \\
\text { ICZN article } 23.3 .7\end{array}$ \\
\hline Pontogammaridae & $\begin{array}{l}\text { Stenogammarus } \\
\text { deminutus }\end{array}$ & (Stebbing, 1906) & $\begin{array}{l}\text { Caspian, } \\
\text { Ponto-Azov }\end{array}$ & valid & $\begin{array}{l}\text { Nom. nov. for Gammarus } \\
\text { minutus G.O. Sars } 1894\end{array}$ \\
\hline Pontogammaridae & $\begin{array}{l}\text { Stenogammarus } \\
\text { macrurus }\end{array}$ & (G.O. Sars, 1894) & $\begin{array}{l}\text { Caspian, } \\
\text { Ponto-Azov }\end{array}$ & valid & \\
\hline Pontogammaridae & $\begin{array}{l}\text { Stenogammarus } \\
\text { micrurus }\end{array}$ & $\begin{array}{l}\text { Derzhavin \& } \\
\text { Pjatakova, } 1996 \\
\end{array}$ & Caspian & valid & \\
\hline Pontogammaridae & Stenogammarus similis & (G.O. Sars, 1894) & $\begin{array}{l}\text { Caspian, } \\
\text { Ponto-Azov }\end{array}$ & valid & \\
\hline Pontogammaridae & $\begin{array}{l}\text { Turcogammarus } \\
\text { aralensis }\end{array}$ & (Uljanin, 1875) & $\begin{array}{l}\text { Aral, Caspian, } \\
\text { Ponto-Azov }\end{array}$ & valid & \\
\hline Pontogammaridae & Turcogammarus spandli & (Karaman, 1931) & Balkan & valid & \\
\hline Pontogammaridae & $\begin{array}{l}\text { Turcogammarus } \\
\text { turcarum }\end{array}$ & (Stock, 1974) & Caucasus & doubtful & $\begin{array}{l}\text { Probably junior synonym of } \\
\text { Pontogammarus setosus } \\
\text { (Schäferna, 1914). Further } \\
\text { research needed. }\end{array}$ \\
\hline Pontogammaridae & $\begin{array}{l}\text { Uroniphargoides } \\
\text { spinicaudatus }\end{array}$ & (Cărăușu, 1943) & $\begin{array}{l}\text { Caspian, } \\
\text { Ponto-Azov }\end{array}$ & valid & \\
\hline Pontogammaridae & $\begin{array}{l}\text { Wolgagammarus } \\
\text { dzjubani }\end{array}$ & $\begin{array}{l}\text { (Mordukhai- } \\
\text { Boltovskoi \& } \\
\text { Ljakhov, 1972) }\end{array}$ & Caspian & valid & \\
\hline \multicolumn{6}{|l|}{ Fossil taxa } \\
\hline Pontogammaridae & Andrussovia bogacevi & Derzhavin, 1927† & Caspian & valid & \\
\hline Pontogammaridae & Andrussovia sokolovi & Derzhavin, 1927† & Caspian & valid & \\
\hline Pontogammaridae & $\begin{array}{l}\text { Andrussovia } \\
\text { vassoievitschi }\end{array}$ & Derzhavin, 1941† & Caspian & valid & \\
\hline Pontogammaridae & Praegmelina andrussovi & Derzhavin, 1927† & Caspian & valid & \\
\hline Pontogammaridae & $\begin{array}{l}\text { Praegmelina } \\
\text { archangelskii }\end{array}$ & Derzhavin, $1927+$ & Caspian & valid & \\
\hline Hellenidae & Hellenis saltatorius & Petunnikoff, $1914 \dagger$ & Caspian & valid & $\begin{array}{l}\text { Uncertain affiliation with } \\
\text { extant Ponto-Caspian taxa }\end{array}$ \\
\hline
\end{tabular}


bioRxiv preprint doi: https://doi.org/10.1101/2021.01.21.427559; this version posted January 21, 2021. The copyright holder for this preprint (which was not certified by peer review) is the author/funder, who has granted bioRxiv a license to display the preprint in perpetuity. It is made available under aCC-BY-NC-ND 4.0 International license.
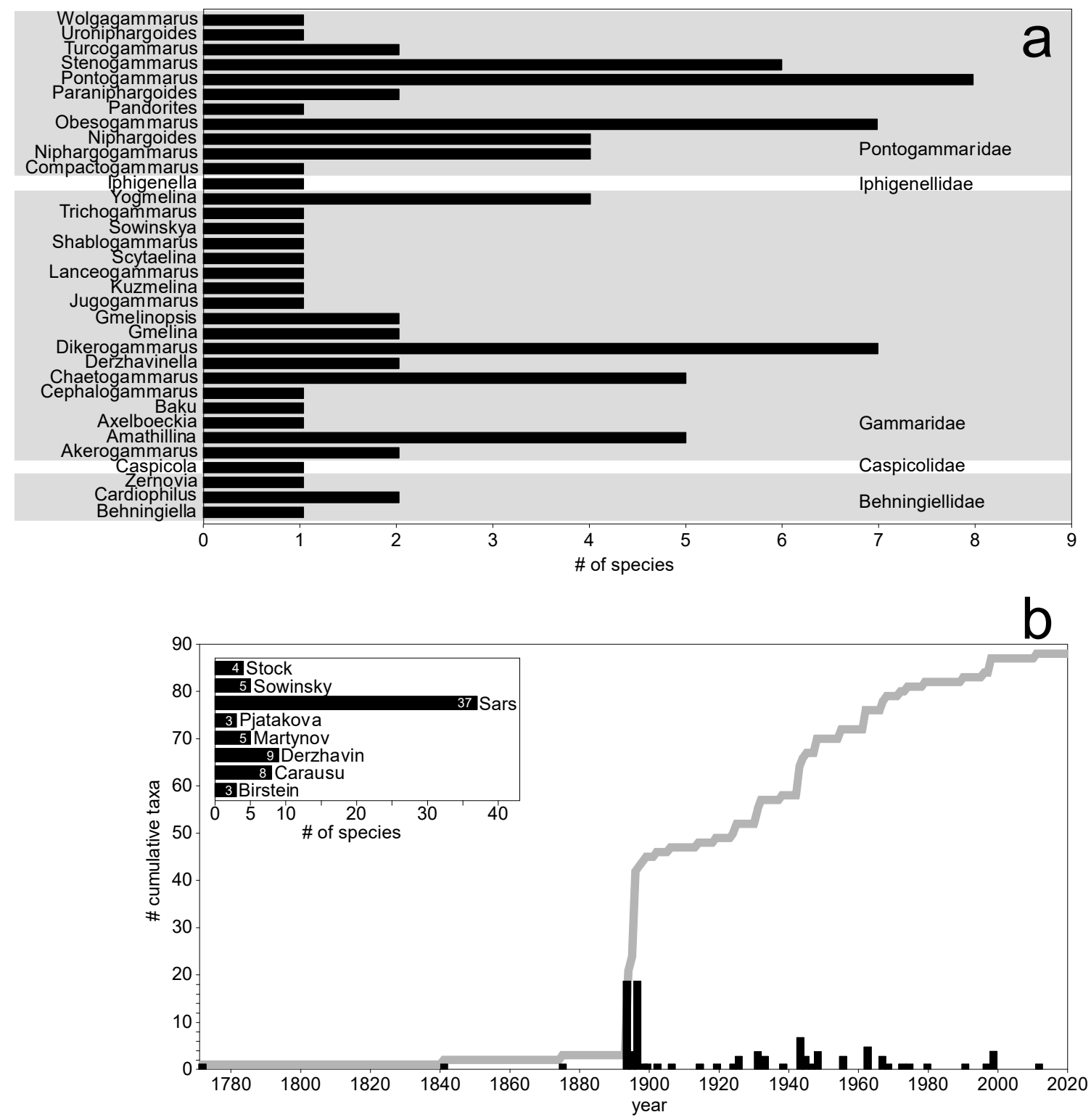

Fig. 1 a) Species richness within genera and families. Only valid and extant species were considered. b) Trends in species descriptions through time. The thick gray line indicates the cumulative number of species while black bars indicate the number of species described in that respective year. The inset graph depicts the number of species described by the most prominent authors

\section{Morphology}

To explore morphological diversity we extracted data only from those original species descriptions or re-descriptions that provided good quality habitus illustrations (73\% of all species) (Cărăuşu 1943; Cărăuşu et al. 1955; Derzhavin 1944, 1948; Sars 1894a, 1894b, 1895, 1896). This was necessary because we used the ratios of various body parts and appendages to total body length. In total, we calculated ratios for 53 traits reflecting as much as possible the overall body shape and functional morphology (see Supplementary information Tables S1-S2 and Fig. S1) (Fišer et al. 2009). The ratios were measured using the Digimizer software (https://www.digimizer.com/). Whenever possible, both sexes were included. We acknowledge that these illustration obtained ratios do not provide the most exhaustive nor precise morphological detail. However, given that these data have a broad 
bioRxiv preprint doi: https://doi.org/10.1101/2021.01.21.427559; this version posted January 21, 2021. The copyright holder for this preprint (which was not certified by peer review) is the author/funder, who has granted bioRxiv a license to display the preprint in perpetuity. It is made available under aCC-BY-NC-ND 4.0 International license.

taxonomic coverage, we consider this analysis as a crucial preliminary step in quantifying and understanding the morphological diversity of Ponto-Caspian amphipods.

Apart from ratios, we also extracted body size information from the literature and included it in the analysis as well. The 53 ratio + body-size dataset was subjected to a Principal Component Analysis (PCA) based on a correlation matrix to visualize morphological gradients and similarity among genera. Analysis was performed using Statistica 8.0 (StatSoft, Inc.,Tulsa, OK, USA).

We find substantial diversity in body shape and size. The habitus of representative species is presented in Fig. 2. Body size varies by almost an order of magnitude (3.5 to $27 \mathrm{~mm}$ ) (Figs. 2, 6). The PCA plot indicates significant morphological disparity (Fig. 3). The first four PCA axes explained 22.76, $14.12,10.17$ and $9.28 \%$ (56.34\%) of the total variation. The first principal component separated species along a gradient from stout bodies with deep coxae and short antennae to slender bodies with shallow coxae and long antennae (Fig. 3a). The second principal component distinguished a gradient along which species were separated by the length of walking appendages and the depth of the tergum (Fig. 3a). The loadings of traits on the PCA axes are presented in Supplementary information Table 3.

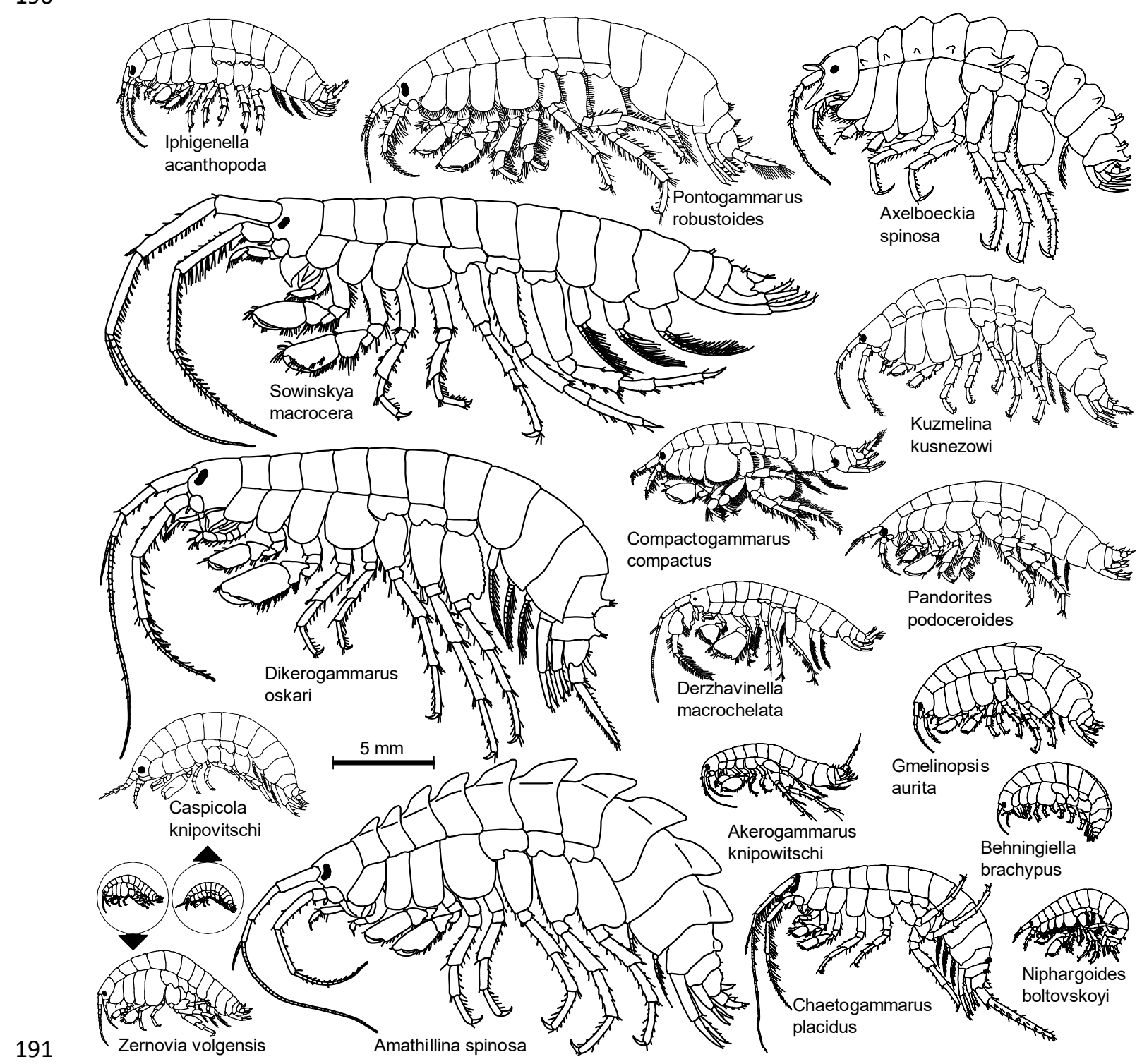


bioRxiv preprint doi: https://doi.org/10.1101/2021.01.21.427559; this version posted January 21, 2021. The copyright holder for this preprint

(which was not certified by peer review) is the author/funder, who has granted bioRxiv a license to display the preprint in perpetuity. It is made available under aCC-BY-NC-ND 4.0 International license.

192

193

194

195

196

197

198

199

200

201

202

203

204

205

206

207

208

209
Fig. 2 Habitus and morphological diversity of Ponto-Caspian amphipods. Caspicola knipovitschi and Zernovia volgensis are shown to scale in circles and enlarged outside the circles. All images are redrawn after the original

There is significant variation with respect to body armature as well. Although most species are generally smooth, there are diverse patterns of ornamentation with either a medial keel that extends throughout different body regions (e.g. Amathillina, Gmelina and Gmelinopsis) to double dorsolateral cuspidation (Kuzmelina), to lateral spines and dorsal protuberances (Axelboeckia) (Fig. 2).

Most genera seem to be relatively well defined in morphospace. However, Amathillina and Obesogammarus overlap broadly with other genera (Fig. 3a). The monotypic genera (shown with black and white symbols in Fig. 3a) are generally distinct from the more speciose ones, often lying towards the extreme ends of the morphological gradients. 
bioRxiv preprint doi: https://doi.org/10.1101/2021.01.21.427559; this version posted January 21, 2021. The copyright holder for this preprint (which was not certified by peer review) is the author/funder, who has granted bioRxiv a license to display the preprint in perpetuity. It is made available under aCC-BY-NC-ND 4.0 International license.
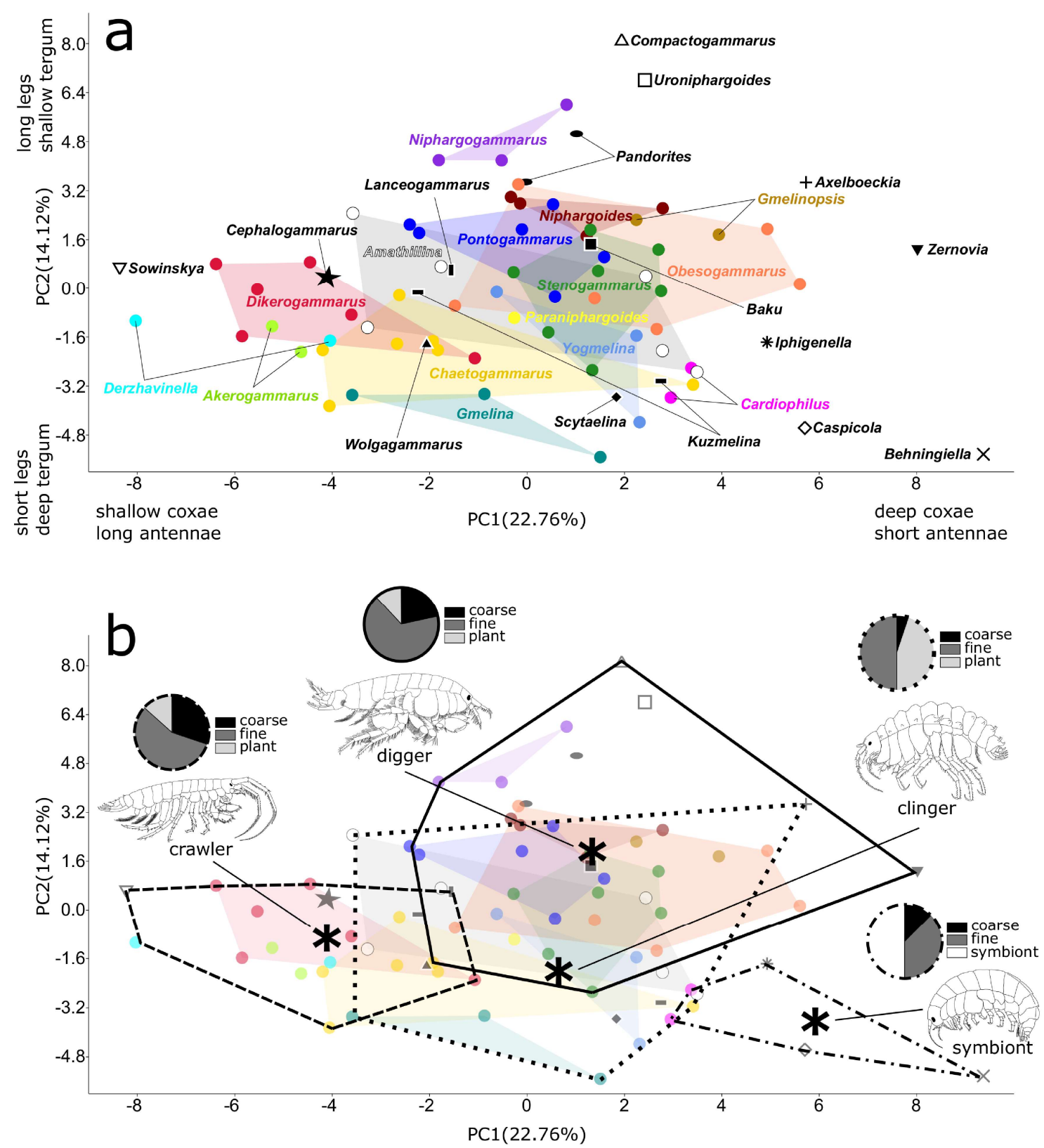

Fig. 3 a) PCA scatterplot depicting the morphological gradients along the first two axes. Genera represented by at least three data points are shown with a uniquely colored convex hull and dots. Monotypic genera are depicted with various black symbols and shapes. b) The same PCA as in a) but with convex hulls delineating putative ecomorphs. Asterisks indicate morph centroid. For each morph a representative species is shown. The pie-charts indicate the proportion of species occurring on various substrates within each ecomorph

\section{Ecology}

To provide a synopsis of ecology we reviewed all the original species descriptions and the relevant literature (Birstein and Romanova 1968; Pjatakova and Tarasov 1996). We gathered data regarding depth (minimum and maximum), habitat (sea, lagoon, lake/reservoir, river and spring), salinity (steno- and/or euryhaline) and substrate type (stone, sand, mud, clay, plant and symbiotic relationships). 
Our review highlights important ecological diversity within the Ponto-Caspian radiation. With respect to habitat, most species live in the sea (67 spp.) and lower courses of rivers (45 spp.), followed by brackish lagoons (26 spp.) and freshwater lakes or reservoirs (27 spp.). Only four species occur exclusively in springs and streams (Table 2, Fig. 4). With respect to salinity, it appears that most species are euryhaline, tolerating both fresh as well as brackish waters. However, salinity preference is not known for many species. With respect to substrate, the great majority of species occur on sandy and muddy substrates, followed by stones and plants. Four species seem to be associated with other organisms such as bivalve mollusks and crayfish (Table 2, Fig. 4). All of the ecological data is summarized in Table 2.

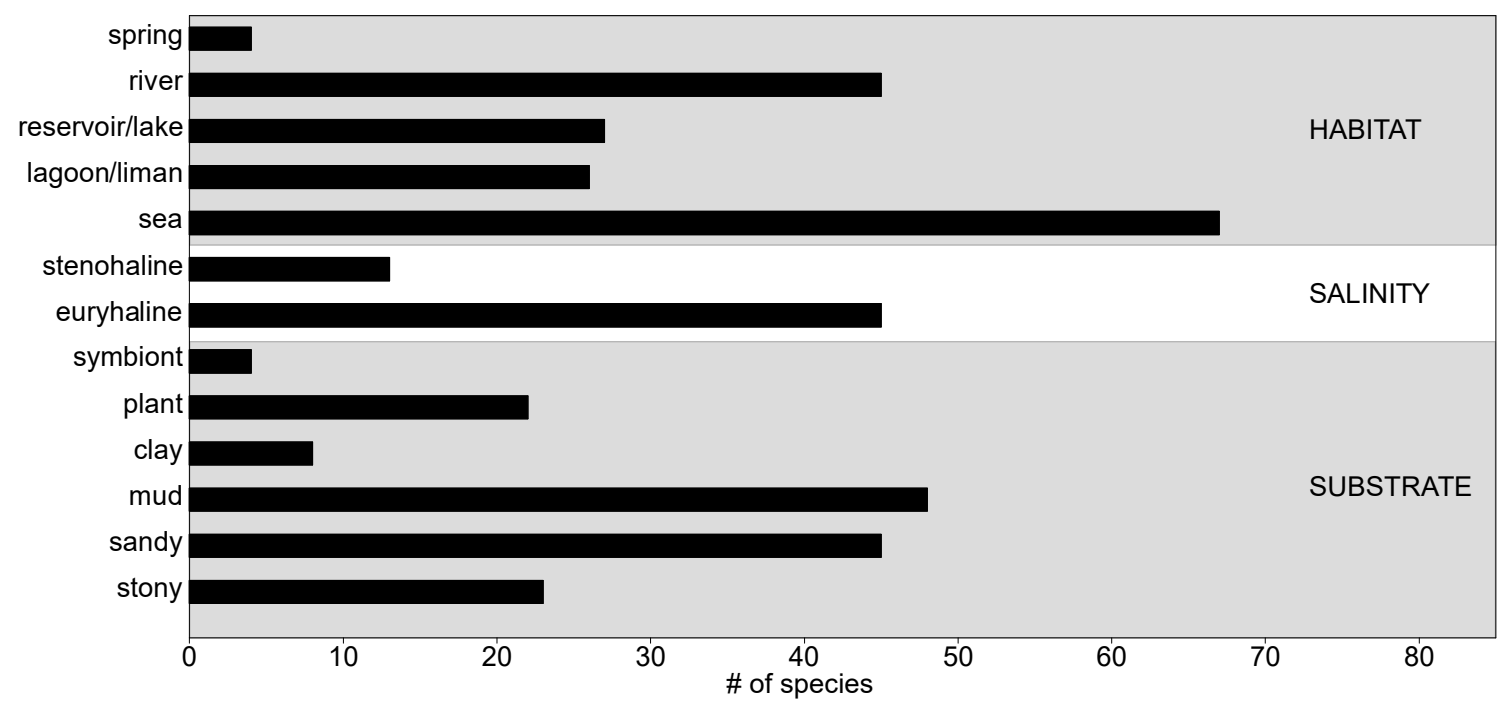

Fig. 4 Number of species occurring on various substrates, habitats and salinities

The depth gradient is broad, ranging from the wet sand of the supra-littoral to more than $500 \mathrm{~m}$ depth (Table 2, Fig. 5). Individual species also seem to be quite plastic and can be found from shallow depths (less than $50 \mathrm{~m}$ ) to more than $200 \mathrm{~m}$. The genera Amathillina, Chaetogammarus, Niphargoides and Pandorites have the broadest depth ranges. Species diversity is the highest in the first $50 \mathrm{~m}$ (79 species), then rapidly decreases to below 10 species in the 250-550 m interval (Fig. 5). The only species known to occur at depths greater than $500 \mathrm{~m}$ is Chaetogammarus pauxillus. 
bioRxiv preprint doi: https://doi.org/10.1101/2021.01.21.427559; this version posted January 21, 2021. The copyright holder for this preprint (which was not certified by peer review) is the author/funder, who has granted bioRxiv a license to display the preprint in perpetuity. It is made available under aCC-BY-NC-ND 4.0 International license.

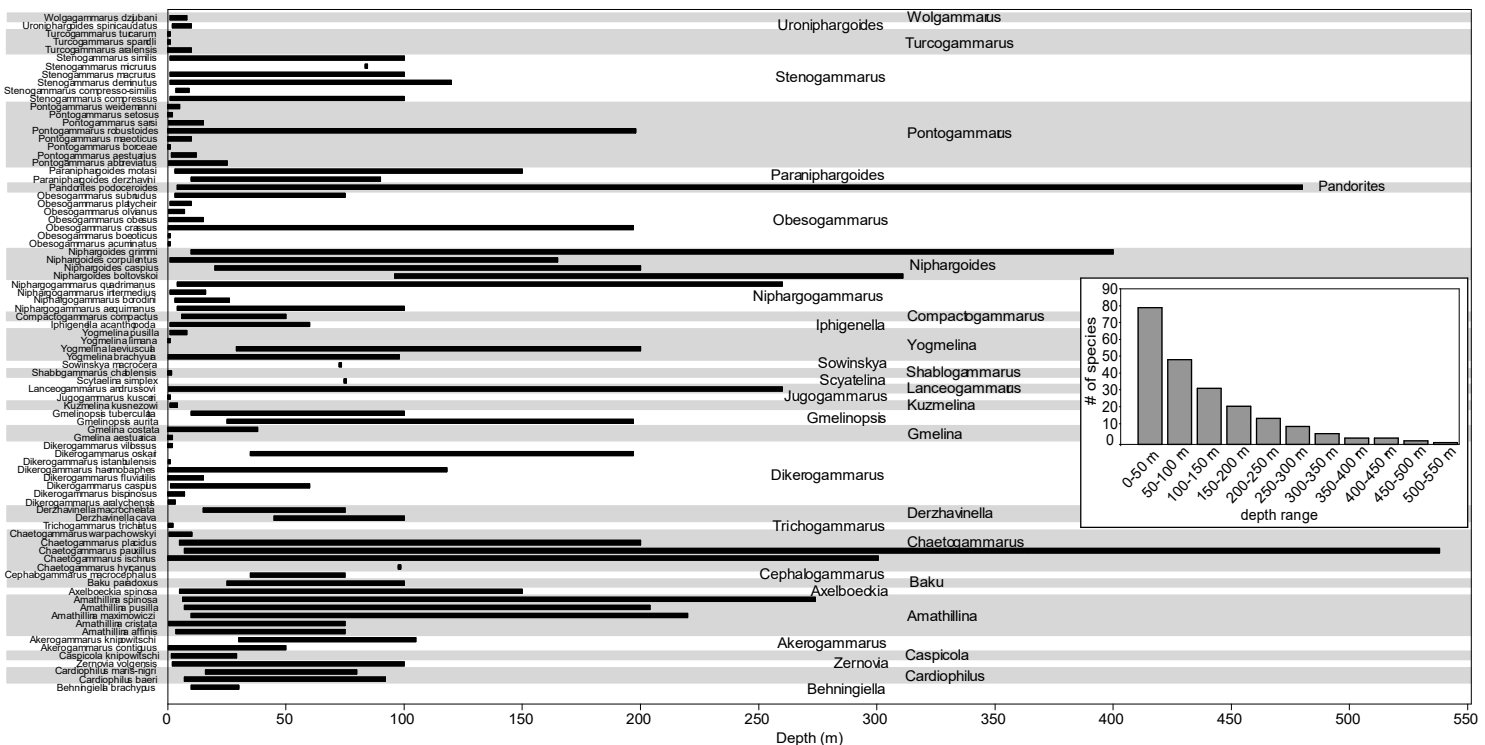

261

262

263

264

265

266

267

268

Fig. 5 Depth ranges structured by taxonomic composition. The inset graph depicts the number of species occurring in $50 \mathrm{~m}$ depth intervals

Table 2. Ecological diversity of Ponto-Caspian gammaroid amphipods.

\begin{tabular}{|c|c|c|c|c|c|c|c|c|c|c|c|c|c|c|c|}
\hline \multirow{2}{*}{ Species } & \multirow{2}{*}{$\begin{array}{l}\text { Min } \\
\text { depth }\end{array}$} & \multirow{2}{*}{$\begin{array}{l}\text { Max } \\
\text { depth }\end{array}$} & \multicolumn{6}{|c|}{ Substrate } & \multirow{2}{*}{ Salinity } & \multicolumn{5}{|c|}{ Habitat } & \multirow{2}{*}{ Ecomorph } \\
\hline & & & sto $^{1}$ & $\operatorname{san}^{2}$ & mud & $\mathrm{cla}^{3}$ & pla $^{4}$ & symbiont & & sea & $\operatorname{lag}^{5}$ & res $^{6}$ & riv $^{7}$ & $\mathrm{spr}^{8}$ & \\
\hline $\begin{array}{c}\text { Behningiella } \\
\text { brachypus }\end{array}$ & 10 & 30 & $x$ & $x$ & & & & & $?$ & $x$ & & & & & symbiont \\
\hline Cardiophilus baeri & 7 & 92 & & & $?$ & $?$ & & Cardium & $?$ & $x$ & & & & & symbiont \\
\hline $\begin{array}{c}\text { Cardiophilus maris- } \\
\text { nigri }\end{array}$ & 16 & 80 & & $x$ & & $\mathrm{x}$ & & Mytilus & $?$ & $x$ & & & & & symbiont \\
\hline Zernovia volgensis & 2 & 100 & & & & & & & $?$ & $x$ & & & $x$ & & digger \\
\hline $\begin{array}{c}\text { Caspicola } \\
\text { knipovitschi }\end{array}$ & 1.5 & 29 & & $x$ & & & & $\begin{array}{l}\text { possibly } \\
\text { molluscs }\end{array}$ & euryh. & $x$ & & & $\mathrm{x}$ & & symbiont \\
\hline $\begin{array}{l}\text { Akerogammarus } \\
\text { contiguus }\end{array}$ & 0.2 & 50 & $x$ & $\mathrm{x}$ & $x$ & & & & $?$ & $x$ & & & & & crawler \\
\hline $\begin{array}{c}\text { Akerogammarus } \\
\text { knipowitschi }\end{array}$ & 30 & 105 & & & $x$ & & & & $?$ & $x$ & & & & & crawler \\
\hline Amathillina affinis & 3.5 & 75 & & & & & $x$ & & euryh. & $x$ & & & & & clinger \\
\hline Amathillina cristata & 0.5 & 75 & & & & & $x$ & & euryh. & $x$ & $x$ & $x$ & $x$ & & clinger \\
\hline $\begin{array}{l}\text { Amathillina } \\
\text { maximowiczi }\end{array}$ & 10 & 220 & & & & & ? & & $?$ & $x$ & $x$ & & & & clinger \\
\hline Amathillina pusilla & 7 & 204 & & & & & $x$ & & $?$ & $x$ & & & & & clinger \\
\hline Amathillina spinosa & 6.4 & 274 & & $x$ & $x$ & & $?$ & & euryh. & $x$ & & & & & clinger \\
\hline Axelboeckia spinosa & 5 & 150 & & & $?$ & & $x$ & & euryh. & $x$ & & & $x$ & & clinger \\
\hline Baku paradoxus & 25 & 100 & & & $x$ & & & & $?$ & $x$ & & & & & digger \\
\hline $\begin{array}{l}\text { Cephalogammarus } \\
\text { macrocephalus }\end{array}$ & 35 & 75 & & & $x$ & & & & $?$ & $x$ & & & & & crawler \\
\hline $\begin{array}{c}\text { Chaetogammarus } \\
\text { hyrcanus }\end{array}$ & & 98 & & & $x$ & & & & $?$ & $x$ & & & & & crawler \\
\hline $\begin{array}{c}\text { Chaetogammarus } \\
\text { ischnus }\end{array}$ & 0 & 300 & $x$ & $x$ & $x$ & & $x$ & & euryh. & $x$ & $x$ & $x$ & $x$ & & crawler \\
\hline $\begin{array}{c}\text { Chaetogammarus } \\
\text { pauxillus }\end{array}$ & 7 & 538 & & $x$ & & & & & euryh. & $x$ & & & & & crawler \\
\hline
\end{tabular}


bioRxiv preprint doi: https://doi.org/10.1101/2021.01.21.427559; this version posted January 21, 2021. The copyright holder for this preprint (which was not certified by peer review) is the author/funder, who has granted bioRxiv a license to display the preprint in perpetuity. It is made available under aCC-BY-NC-ND 4.0 International license.

\begin{tabular}{|c|c|c|c|c|c|c|c|c|c|c|c|c|c|c|c|}
\hline $\begin{array}{c}\text { Chaetogammarus } \\
\text { placidus }\end{array}$ & 5 & 200 & & & $\mathrm{x}$ & & & & euryh. & $\mathrm{x}$ & & & $x$ & & crawler \\
\hline $\begin{array}{c}\text { Chaetogammarus } \\
\text { warpachowskyi }\end{array}$ & 0.5 & 10 & & $x$ & $\mathrm{x}$ & & $\mathrm{x}$ & & euryh. & $\mathrm{x}$ & $\mathrm{x}$ & $x$ & $x$ & & clinger \\
\hline Derzhavinella cava & 45 & 100 & & & & & & & $?$ & $x$ & & & & & crawler \\
\hline $\begin{array}{l}\text { Derzhavinella } \\
\text { macrochelata }\end{array}$ & 15 & 75 & & & $\mathrm{x}$ & & & & $?$ & $\mathrm{x}$ & & & & & crawler \\
\hline $\begin{array}{c}\text { Dikerogammarus } \\
\text { aralychensis }\end{array}$ & 0.2 & 3 & & $x$ & $\mathrm{x}$ & & & & stenoh. & & & $x$ & $\mathrm{x}$ & & digger \\
\hline $\begin{array}{c}\text { Dikerogammarus } \\
\text { bispinosus }\end{array}$ & 0 & 7 & $\mathrm{x}$ & $\mathrm{x}$ & & & & & euryh. & $\mathrm{x}$ & & $\mathrm{x}$ & $\mathrm{x}$ & & crawler \\
\hline $\begin{array}{c}\text { Dikerogammarus } \\
\text { caspius }\end{array}$ & 1.2 & 60 & $x$ & & & & & & euryh. & $\mathrm{x}$ & & $\mathrm{x}$ & $\mathrm{x}$ & & crawler \\
\hline $\begin{array}{c}\text { Dikerogammarus } \\
\text { fluviatilis }\end{array}$ & 0 & 15 & $x$ & $x$ & $\mathrm{x}$ & & $\mathrm{x}$ & & euryh. & & & & $\mathrm{x}$ & & crawler \\
\hline $\begin{array}{c}\text { Dikerogammarus } \\
\text { gruberi }\end{array}$ & & & & & & & & & $?$ & & & $\mathrm{x}$ & & & $?$ \\
\hline $\begin{array}{c}\text { Dikerogammarus } \\
\text { haemobaphes }\end{array}$ & 0 & 118 & $x$ & $x$ & $\mathrm{x}$ & & & & euryh. & $x$ & $x$ & $x$ & $\mathrm{x}$ & & crawler \\
\hline $\begin{array}{c}\text { Dikerogammarus } \\
\text { istanbulensis }\end{array}$ & 0.2 & 1 & & & $\mathrm{x}$ & & & & $?$ & & & $\mathrm{x}$ & & & crawler \\
\hline $\begin{array}{c}\text { Dikerogammarus } \\
\text { oskari }\end{array}$ & 35 & 197 & & & $\mathrm{x}$ & & & & $?$ & $\mathrm{x}$ & & & & & crawler \\
\hline $\begin{array}{c}\text { Dikerogammarus } \\
\text { villosus }\end{array}$ & 0 & 2 & $x$ & & & & $x$ & & euryh. & $x$ & $x$ & $x$ & $x$ & & crawler \\
\hline Gmelina aestuarica & 0 & 2 & & $\mathrm{x}$ & $x$ & & $\mathrm{x}$ & & euryh. & & $x$ & & $x$ & & clinger \\
\hline Gmelina costata & 0 & 38 & $x$ & $x$ & & & $x$ & & euryh. & $x$ & & & $x$ & & clinger \\
\hline Gmelinopsis aurita & 25 & 197 & & & & & & & $?$ & $x$ & & & & & digger \\
\hline $\begin{array}{l}\text { Gmelinopsis } \\
\text { tuberculata }\end{array}$ & 10 & 100 & $x$ & & & & & & euryh. & $x$ & $x$ & & $\mathrm{x}$ & & digger \\
\hline $\begin{array}{l}\text { Kuzmelina } \\
\text { kusnezowi }\end{array}$ & 1 & 4 & & & $x$ & & & & euryh. & $\mathrm{x}$ & $x$ & & $\mathrm{x}$ & & clinger \\
\hline $\begin{array}{c}\text { Jugogammarus } \\
\text { kusceri }\end{array}$ & 0 & 1 & $x$ & $x$ & & & & & stenoh. & & & & & $x$ & clinger \\
\hline $\begin{array}{c}\text { Lanceogammarus } \\
\text { andrussowi }\end{array}$ & 0.5 & 260 & & $x$ & & & $x$ & & euryh. & $\mathrm{x}$ & $\mathrm{x}$ & $\mathrm{x}$ & & & crawler \\
\hline Scytaelina simplex & & 75 & & & & & & & $?$ & $x$ & & & & & clinger \\
\hline $\begin{array}{c}\text { Shablogammarus } \\
\text { shablensis }\end{array}$ & 0 & 1.5 & & & $\mathrm{x}$ & & $x$ & & euryh. & & $x$ & $\mathrm{x}$ & $\mathrm{x}$ & & crawler \\
\hline $\begin{array}{l}\text { Sowinskya } \\
\text { macrocera }\end{array}$ & & 73 & & & $\mathrm{x}$ & & & & $?$ & $\mathrm{x}$ & & & & & crawler \\
\hline $\begin{array}{c}\text { Trichogammarus } \\
\text { trichiatus }\end{array}$ & 0 & 2 & $x$ & $x$ & & & & & euryh. & & $\mathrm{x}$ & $\mathrm{x}$ & $x$ & & crawler \\
\hline $\begin{array}{l}\text { Yogmelina } \\
\text { brachyura }\end{array}$ & 0.3 & 98 & & $x$ & $\mathrm{x}$ & & $x$ & & $?$ & $\mathrm{x}$ & & & & & clinger \\
\hline $\begin{array}{l}\text { Yogmelina } \\
\text { laeviuscula }\end{array}$ & 29 & 200 & & & $\mathrm{x}$ & & & & $?$ & $\mathrm{x}$ & & & & & clinger \\
\hline Yogmelina limana & & 1 & & $x$ & $x$ & & $x$ & & euryh. & & $x$ & & $?$ & & clinger \\
\hline Yogmelina pusilla & 1 & 8 & & $x$ & $x$ & & $x$ & & euryh. & $x$ & $\mathrm{x}$ & & $?$ & & clinger \\
\hline $\begin{array}{c}\text { Iphigenella } \\
\text { acanthopoda }\end{array}$ & 1 & 60 & & & & & & $\begin{array}{c}\text { possibly } \\
\text { Astacidae }\end{array}$ & euryh. & $\mathrm{x}$ & $x$ & $x$ & $x$ & & symbiont \\
\hline $\begin{array}{c}\text { Compactogammarus } \\
\text { compactus }\end{array}$ & 6 & 50 & & $x$ & $\mathrm{x}$ & & & & euryh. & $\mathrm{x}$ & $\mathrm{x}$ & & $x$ & & digger \\
\hline $\begin{array}{c}\text { Niphargogammarus } \\
\text { aequimanus }\end{array}$ & 4 & 100 & & & & & & & stenoh. & $x$ & & & & & digger \\
\hline $\begin{array}{c}\text { Niphargogammarus } \\
\text { borodini }\end{array}$ & 3 & 26 & & & & & & & $?$ & $x$ & & & & & digger \\
\hline $\begin{array}{c}\text { Niphargogammarus } \\
\text { intermedius }\end{array}$ & 1 & 16 & & $x$ & $\mathrm{x}$ & $x$ & & & euryh. & & & & $\mathrm{x}$ & & digger \\
\hline
\end{tabular}


bioRxiv preprint doi: https://doi.org/10.1101/2021.01.21.427559; this version posted January 21, 2021. The copyright holder for this preprint (which was not certified by peer review) is the author/funder, who has granted bioRxiv a license to display the preprint in perpetuity. It is made available under aCC-BY-NC-ND 4.0 International license.

\begin{tabular}{|c|c|c|c|c|c|c|c|c|c|c|c|c|c|c|}
\hline $\begin{array}{c}\text { Niphargogammarus } \\
\text { quadrimanus }\end{array}$ & 4 & 260 & & & $x$ & & & stenoh. & $x$ & & & & & digger \\
\hline $\begin{array}{c}\text { Niphargoides } \\
\text { boltovskoyi }\end{array}$ & 96 & 311 & & & $x$ & & & $?$ & $x$ & & & & & digger \\
\hline $\begin{array}{l}\text { Niphargoides } \\
\text { caspius }\end{array}$ & 20 & 200 & & & $x$ & & & stenoh. & $x$ & & & & & digger \\
\hline $\begin{array}{l}\text { Niphargoides } \\
\text { corpulentus }\end{array}$ & 1 & 165 & & & $x$ & & & euryh. & $x$ & & & $x$ & & digger \\
\hline $\begin{array}{c}\text { Niphargoides } \\
\text { grimmi }\end{array}$ & 10 & 400 & & & $x$ & & & stenoh. & $x$ & & & & & digger \\
\hline $\begin{array}{c}\text { Obesogammarus } \\
\text { acuminatus }\end{array}$ & 0.2 & 1 & & & & & $x$ & euryh. & $x$ & $x$ & & & & digger \\
\hline $\begin{array}{c}\text { Obesogammarus } \\
\text { boeoticus }\end{array}$ & 0.2 & 1 & $x$ & $x$ & & & & stenoh. & & & $x$ & & & digger \\
\hline $\begin{array}{c}\text { Obesogammarus } \\
\text { crassus }\end{array}$ & 0.2 & 197 & $x$ & $x$ & $x$ & & $x$ & euryh. & $x$ & $x$ & $x$ & $x$ & & digger \\
\hline $\begin{array}{c}\text { Obesogammarus } \\
\text { obesus }\end{array}$ & 0.5 & 15 & $x$ & $x$ & & & $x$ & euryh. & $x$ & $x$ & $x$ & $x$ & & digger \\
\hline $\begin{array}{c}\text { Obesogammarus } \\
\text { olvianus }\end{array}$ & 0.5 & 7 & & & $x$ & & & euryh. & $x$ & & & & & digger \\
\hline $\begin{array}{c}\text { Obesogammarus } \\
\text { platycheir }\end{array}$ & 1 & 10 & & $x$ & & & & euryh. & $x$ & & & $x$ & & digger \\
\hline $\begin{array}{c}\text { Obesogammarus } \\
\text { subnudus }\end{array}$ & 3 & 75 & & $x$ & & & & $?$ & $x$ & & & $x$ & & digger \\
\hline $\begin{array}{c}\text { Pandorites } \\
\text { podoceroides }\end{array}$ & 4 & 480 & & $x$ & $x$ & & & euryh. & $x$ & & & & & digger \\
\hline $\begin{array}{c}\text { Paraniphargoides } \\
\text { derzhavini }\end{array}$ & 10 & 90 & & $x$ & $x$ & & & ? & $x$ & & & & & digger \\
\hline $\begin{array}{c}\text { Paraniphargoides } \\
\text { motasi }\end{array}$ & 3 & 150 & & $x$ & $x$ & & & ? & & & & $x$ & & digger \\
\hline $\begin{array}{c}\text { Pontogammarus } \\
\text { abbreviatus }\end{array}$ & 0.5 & 25 & & $x$ & $x$ & $x$ & & euryh. & $x$ & & $x$ & $x$ & & digger \\
\hline $\begin{array}{c}\text { Pontogammarus } \\
\text { aestuarius }\end{array}$ & 1.5 & 12 & $x$ & $x$ & $x$ & & & euryh. & $x$ & $x$ & & $x$ & & digger \\
\hline $\begin{array}{c}\text { Pontogammarus } \\
\text { borceae }\end{array}$ & 0 & 0.1 & & $x$ & & & & euryh. & $x$ & $x$ & & $x$ & & digger \\
\hline $\begin{array}{c}\text { Pontogammarus } \\
\text { maeoticus }\end{array}$ & 0 & 10 & & $x$ & & & & euryh. & $x$ & $x$ & $x$ & $x$ & & digger \\
\hline $\begin{array}{c}\text { Pontogammarus } \\
\text { robustoides }\end{array}$ & 0 & 198 & $x$ & $x$ & $x$ & & $x$ & euryh. & $x$ & $x$ & $x$ & $x$ & & digger \\
\hline $\begin{array}{c}\text { Pontogammarus } \\
\text { sarsi }\end{array}$ & 0.5 & 15 & & $x$ & $x$ & $x$ & & euryh. & & $x$ & $x$ & $x$ & & digger \\
\hline $\begin{array}{l}\text { Pontogammarus } \\
\text { setosus }\end{array}$ & 0 & 2 & $x$ & $x$ & $x$ & & $x$ & stenoh. & & & & $x$ & $x$ & digger \\
\hline $\begin{array}{c}\text { Pontogammarus } \\
\text { weidemanni }\end{array}$ & 0 & 5 & & $x$ & & & & euryh. & $x$ & $x$ & & & & digger \\
\hline $\begin{array}{c}\text { Stenogammarus } \\
\text { compressus }\end{array}$ & 1 & 100 & & & $x$ & & & euryh. & $x$ & & $x$ & $x$ & & digger \\
\hline $\begin{array}{l}\text { Stenogammarus } \\
\text { compresso-similis }\end{array}$ & 3.5 & 9 & $x$ & $x$ & $x$ & $x$ & & euryh. & $x$ & & & $x$ & & digger \\
\hline $\begin{array}{c}\text { Stenogammarus } \\
\text { deminutus }\end{array}$ & 1 & 120 & & & & & & euryh. & $x$ & & $x$ & $x$ & & digger \\
\hline $\begin{array}{c}\text { Stenogammarus } \\
\text { macrurus }\end{array}$ & 1 & 100 & $x$ & $x$ & $x$ & $x$ & & euryh. & $x$ & & $x$ & $x$ & & digger \\
\hline $\begin{array}{l}\text { Stenogammarus } \\
\text { micrurus }\end{array}$ & 84 & 84 & & & $x$ & & & ? & $x$ & & & & & digger \\
\hline $\begin{array}{c}\text { Stenogammarus } \\
\text { similis }\end{array}$ & 1 & 100 & $x$ & $x$ & $x$ & $x$ & $x$ & stenoh. & $x$ & & $x$ & & & digger \\
\hline $\begin{array}{c}\text { Turcogammarus } \\
\text { aralensis }\end{array}$ & 0 & 10 & $x$ & $x$ & & & & euryh. & $x$ & & $x$ & $x$ & & digger \\
\hline $\begin{array}{l}\text { Turcogammarus } \\
\text { spandli }\end{array}$ & 0 & 0.5 & $x$ & & & & & stenoh. & & & & $x$ & $x$ & crawler \\
\hline
\end{tabular}




\begin{tabular}{|c|c|c|c|c|c|c|c|c|c|c|c|}
\hline $\begin{array}{l}\text { Turcogammarus } \\
\text { turcarum }\end{array}$ & 0 & 1 & $x$ & $x$ & & stenoh. & & & & $x$ & crawler \\
\hline $\begin{array}{c}\text { Uroniphargoides } \\
\text { spinicaudatus }\end{array}$ & 2 & 10 & & $x$ & $x$ & stenoh. & $x$ & & $x$ & & digger \\
\hline $\begin{array}{c}\text { Wolgagammarus } \\
\text { dzjubani }\end{array}$ & 1 & 8 & & $x$ & & stenoh. & & $x$ & $x$ & & digger \\
\hline
\end{tabular}

$269{ }^{1}$-stony, ${ }^{2}$-sandy, ${ }^{3}$-clay, ${ }^{4}$-plant, ${ }^{5}$-lagoon, ${ }^{6}$-reservoir/lake, ${ }^{7}$-river, ${ }^{8}$-spring

270

271

272

\section{Proposed ecomorphs}

273 By integrating morphology and substrate type we aimed to classify the species into putative ecomorphs. Specifically, we looked for common morphological characteristics among taxa, while taking into account their similarity in PCA morphospace. We also took into account previous informal groupings of genera (Barnard and Barnard 1983). Once these groups were identified, their substrate preference was established by estimating the proportion of species occurring on a particular substrate. The substrate classification was simplified and divided into four groups: coarse (corresponding to stones and gravel), fine (corresponding to sand, mud and clay), plant and symbiotic. We acknowledge that this is a somewhat arbitrary approach. However, more sophisticated analyses could not be performed given the scarce data at hand. Quantitative data regarding ecology (substrate or trophic niche) are only limited to a few invasive species. Likewise, morphology is incompletely known in many species (especially mouthparts). We emphasize that our goal here was to provide a first exploratory step into understanding the connection between morphology and ecology.

We tentatively defined four ecomorphs: clingers, crawlers, diggers and symbionts. Loosely, these ecomorphs correspond with the currently recognized families and informal groupings of Barnard \& Barnard (1983): crawlers with Gammaridae or "Echinogammarids" + "Dikerogammarids" (sensu Barnard \& Barnard, 1983), clingers with Gammaridae or "Gmelinids" (sensu Barnard \& Barnard, 1983), diggers with Pontogammaridae or "Pontogammarids" + "Compactogammarids" (sensu Barnard \& Barnard, 1983), and symbionts with Behningiellidae, Caspicolidae and Iphigenellidae or "Cardiophilids" (sensu Barnard \& Barnard, 1983). Below we describe the morphological and ecological peculiarities of each ecomorph.

1) Clinger. Stout body often keeled and/or ornamented with spines and tubercles, antennae are slender, short to medium length, coxal plates medium to deep, gnathopods weak, and pereopods short to medium length with pairs 3-4 strongly opposable to pairs 5-7 (Fig. 6). Clingers are intermediate in morphospace between crawlers and diggers, although there is significant overlap significantly with the latter group (Fig. 3b). Most species are associated with plants and fine substrate (Fig. 3b). Around $19 \%$ of all species belong to this ecomorph. Taxonomic composition is given in Table

2) Crawler. Body is slender and generally smooth, antennae are long and slender, coxal plates shallow, pereopods slender, short to medium, gnathopods generally strong, and uropods long (Fig. 6). It is generally well-defined in morphospace having little overlap with clingers and diggers (Fig. 3b). Species are mainly associated with fine and coarse substrates (Fig. 3b). Around $26 \%$ of species belong to this ecomorph. Taxonomic composition is given in Table 2. Representative genera: Chaetogammarus and Dikerogammarus.

3) Digger. Stout body and almost exclusively smooth, antennae very short and thick, with $1^{\text {st }}$ article of antenna 1 often swollen, coxal plates deep, gnathopods generally strong, pereopods medium to long, with broadened articles often fringed with long and dense setae (Fig. 6). Diggers are very distinct in morphospace from crawlers and symbionts, but overlap noticeably with clingers (Fig. 3b). Species of 
this ecomorph predominantly occur on fine substrates and are characterized by a fossorial behavior (Fig. 3b). This appears to be the most common ecomorph since almost half of the Ponto-Caspian species are classified as diggers (49\%). Taxonomic composition is given in Table 2. Representative genera: Pontogammarus and Niphargoides.

4) Symbiont. Very stout and generally minute bodies, with well-developed coxal plates and pereopod bases, usually characterized by diminished mouthparts (palps of maxilla 2 and maxilliped), pleon, urosome, antennae and pereopods (Fig. 6). The gnathopods can be very specialized (Caspicola and Iphigenella), or rudimentary (Behningiella and Cardiophilus). This ecomorph is the most distinct in morphospace, with hardly any overlap (Fig. 3b). Its species are known to live on or inside bivalve mollusks (Cardiophilus and Caspicola), or commensals with crayfish (Iphigenella). This ecomorph is the rarest and accounts for $6 \%$ of all species. Taxonomic composition is given in Table 2 .

Representative genera: Cardiophilus and Iphigenella.
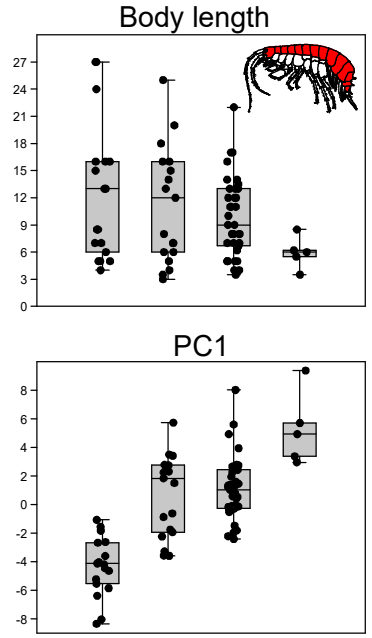

Pereon length

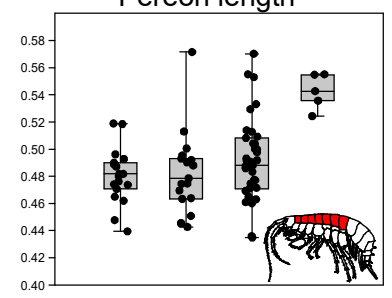

Pleon length

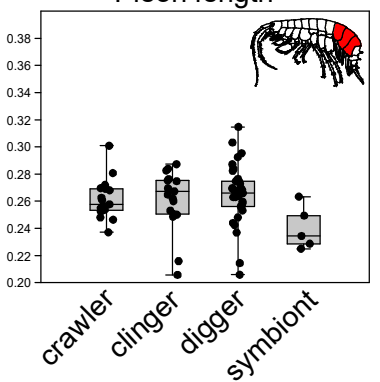

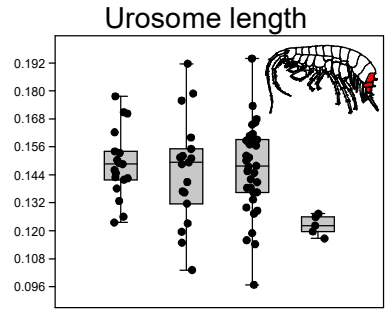

Antenna 1 length

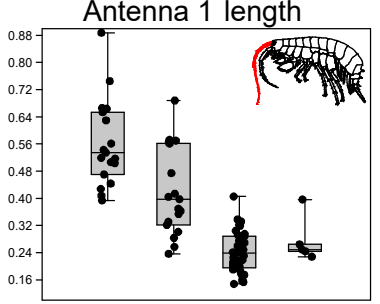

Antenna 2 length

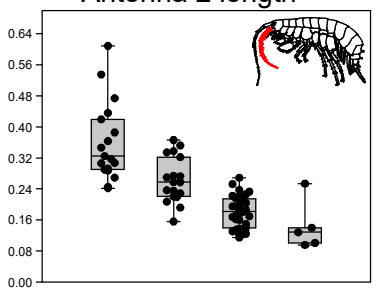

Gnathopod 2 palm

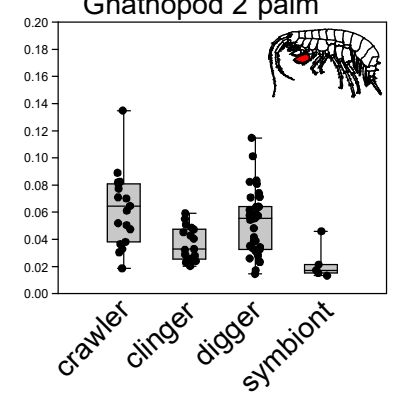

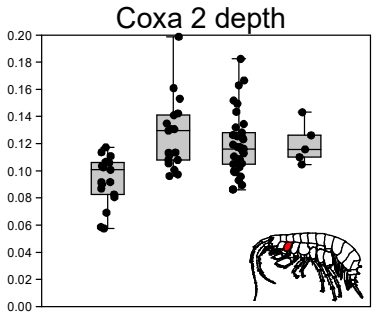

Basis 7 width

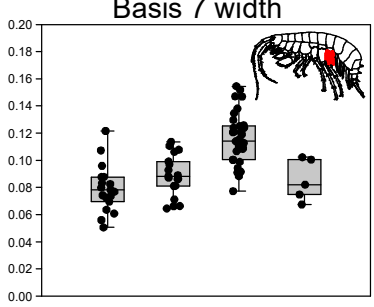

Pereopod 7 length
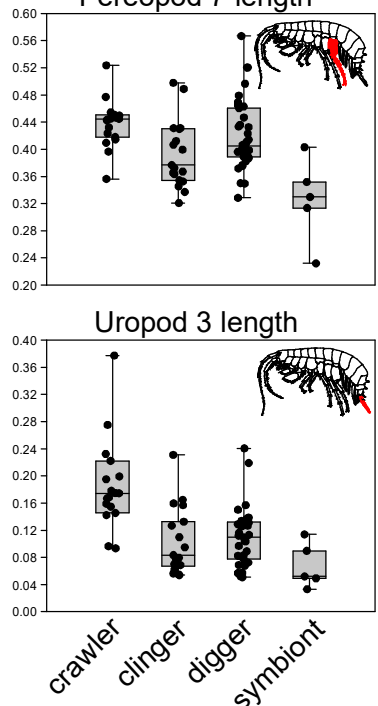

Fig. 6 Boxplots comparing selected traits among the four proposed ecomorphs. PC1 refers to the first principal component resulting from the PCA analysis. It mainly describes the gradient from slender bodies with long antennae (negative values) to stout bodies with short antennae (positive values). All traits except body length and PC1 values are presented relative to total body length 


\section{Discussion}

Our study reviewed and quantified for the first time the rich taxonomic, ecological and morphological diversity of Ponto-Caspian amphipods. Although we consider these findings preliminary, our synopsis will serve as a foundation for future eco-evolutionary and systematic studies. Below we discuss the evidence accrued so far that point towards a remarkable, yet unrecognized adaptive radiation. Within each of the following sub-sections we also highlight the gaps in existing knowledge and recommend further research.

\section{Ponto-Caspian gammarid amphipods - an adaptive radiation?}

The main prerequisites that define an adaptive radiation are: monophyly, species sympatry, speciation rate increase, and ecomorphological divergence (Schluter 2000; Simões et al. 2016). With respect to Ponto-Caspian amphipods the sympatry criterion is the most readily fulfilled since most of the species co-occur in the Caspian Sea and Lower Volga (Table 1). Furthermore, most species seem to be widespread in the Caspian Sea, occurring in all of its main areas (north, middle and southern) (Pjatakova and Tarasov 1996). A significant number of species are also found in sympatry in the Ponto-Azov region (Cărăuşu et al. 1955).

The monophyly condition is supported by recent molecular phylogenies which indicate that several morphologically disparate Ponto-Caspian genera form a well-supported clade (Copilaş-Ciocianu, Borko, et al. 2020; Hou et al. 2014; Hou and Sket 2016; Sket and Hou 2018). Although relatively few taxa have been sequenced so far, it is likely that the remaining species would fall within the same clade. The Ponto-Caspian amphipod radiation also satisfies the requirement of speciation rate increase since it experienced a higher diversification rate in comparison to its sister clades (Hou et al. 2014).

We consider that our current study fulfills, at least partially, the criterion of ecomorphological divergence, which is perhaps the most relevant to the adaptive radiation model. We highlight significant ecological and morphological disparity within the Ponto-Caspian amphipod radiation. Along an order of magnitude body-size gradient, morphology ranges from minute (several millimeters), stout-bodied symbiotic species with attenuated appendages, to large and slender (several centimeters), stocky and setose, or heavily armored species. Likewise, ecological diversity is also remarkable, with species being encountered along a $>500 \mathrm{~m}$ depth gradient on virtually all types of substrates and water bodies (mountain springs to deep sea). By integrating morphology and ecology, we propose a provisional classification into four main ecomorphs: clingers, crawlers, diggers and symbionts. Although this classification is only tentative, we consider it a necessary first step towards understanding the evolution of Ponto-Caspian amphipods. We highlight that these ecomorphs have potential analogues in distantly related marine or Lake Baikal taxa that occupy similar habitats (see Morphological evolution section below), further strengthening the environmentphenotype association.

Overall, it appears that Ponto-Caspian amphipods fulfill, at least to some extent, the main prerequisites of the adaptive radiation model. However, our findings provide only a first glimpse. Extensive further research is needed to corroborate the patterns highlighted herein. Specifically, the criteria of monophyly and speciation rate increase have to be tested on larger multilocus phylogenies with a greater taxonomic coverage. The morphology-environment association needs to be refined with newly collected field data. Specifically, fine-scale morphometry of functionally relevant traits coupled with trophic niche (gut content DNA metabarcoding and stable isotopes) and ecology (depth, substrate and salinity) in a phylogenetic context will provide a more comprehensive ecomorphological understanding. Furthermore, it is important to test whether these ecomorphs have a common ancestor or evolved several times independently (Trontelj et al. 2012). It is likely that upon more detailed investigation they could be split into more specialized forms. Comparative 
transcriptomics and genomics could provide important insight into adaptation and selection at the molecular level. A well-sampled time-calibrated molecular phylogeny could also prove invaluable for understanding the historical circumstances that promote the evolution of invasive species.

\section{Morphological evolution}

Recent molecular phylogenies revealed that the morphologically diverse Ponto-Caspian amphipod radiation is nested within the genus Echinogammarus (Hou and Sket 2016; Sket and Hou 2018), which is characterized by morphological conservatism (Pinkster 1993). This is in good agreement with previous hypotheses that postulated a close relationship between these two groups (Barnard and Barnard 1983). A similar pattern is also encountered in the two highly diverse Baikal amphipod radiations which are classified into several families (Hou and Sket 2016; Lowry and Myers 2013), yet they are both nested within the genus Gammarus (Hou et al. 2011, 2014; Macdonald et al. 2005; Naumenko et al. 2017), notorious for its low morphological diversity, morphological crypsis (CopilașCiocianu and Petrusek 2015; Katouzian et al. 2016; Mamos et al. 2014) and generalist ecology (MacNeil et al. 1997; Piscart et al. 2011). And yet again the same pattern appears in the distantly related American genus Hyalella where morphologically conserved riverine species (Witt et al. 2006) colonized the ancient Titicaca Lake multiple times, giving rise to a remarkable array of forms (Adamowicz et al. 2018; González and Coleman 2002; Jurado-Rivera et al. 2020). These compelling patterns indicate that species living in ephemeral, highly fluctuating and ecologically limited environments (springs, streams, rivers and shallow lakes/ponds) are under stabilizing selection for maintaining a generalist life-style and a conserved, non-specialized morphology (Wellborn and Broughton 2008). On the other hand, species inhabiting stable ancient lakes with broad niche space are probably under disruptive selective pressures which in turn promote specialization and ecological speciation (Seehausen 2015; Wellborn and Langerhans 2015). Thus, it would seem that the ecological transition from ephemeral habitats to long-lived ancient lakes promotes adaptive radiations in some freshwater amphipod groups. These intriguing patterns are worth pursuing further and could shed more light on the role of ecological opportunity in driving adaptive radiations. 
bioRxiv preprint doi: https://doi.org/10.1101/2021.01.21.427559; this version posted January 21, 2021. The copyright holder for this preprint (which was not certified by peer review) is the author/funder, who has granted bioRxiv a license to display the preprint in perpetuity. It is made available under aCC-BY-NC-ND 4.0 International license.

a) symbiont

(1)

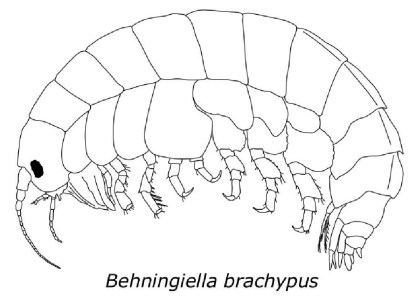

(2)

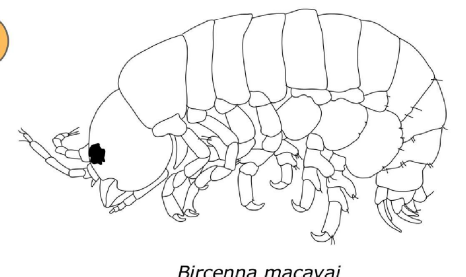

b) digger
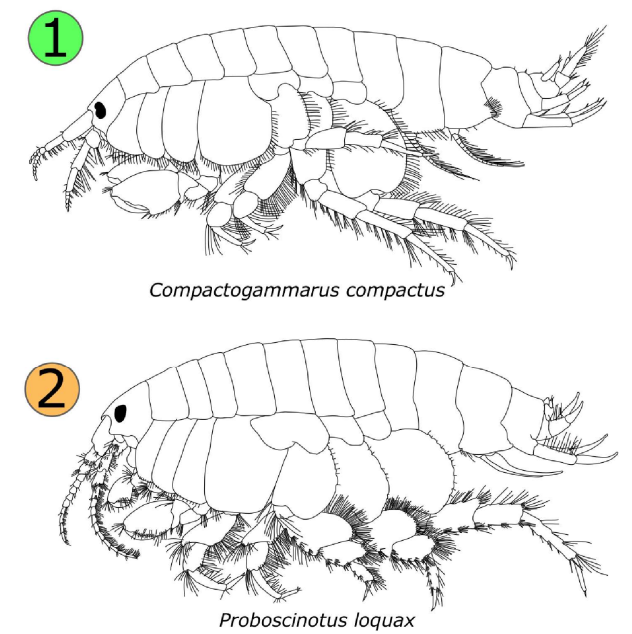

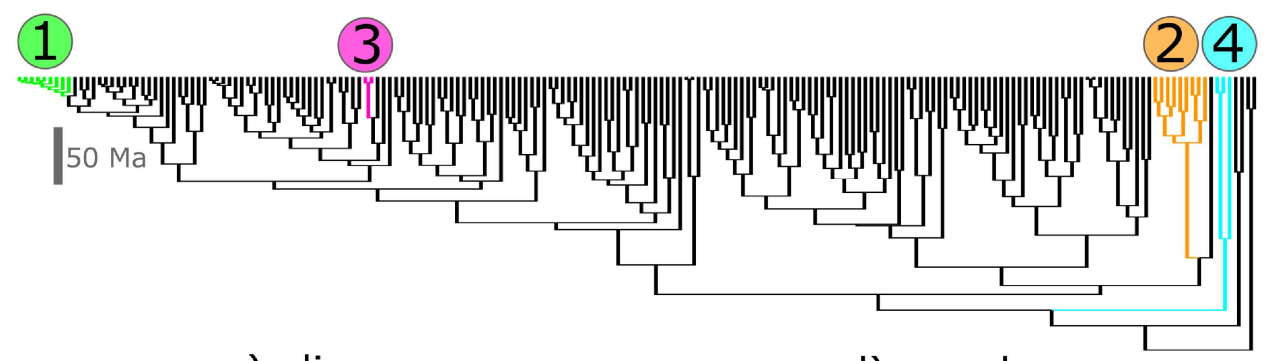

c) clinger

(1)
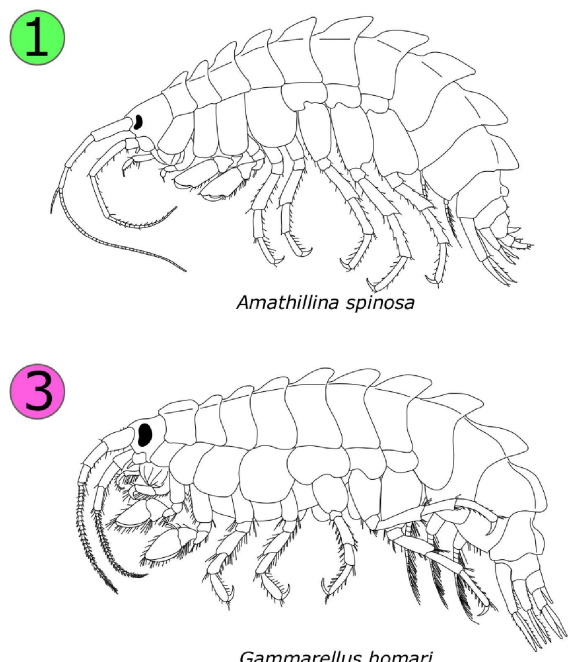

d) crawler
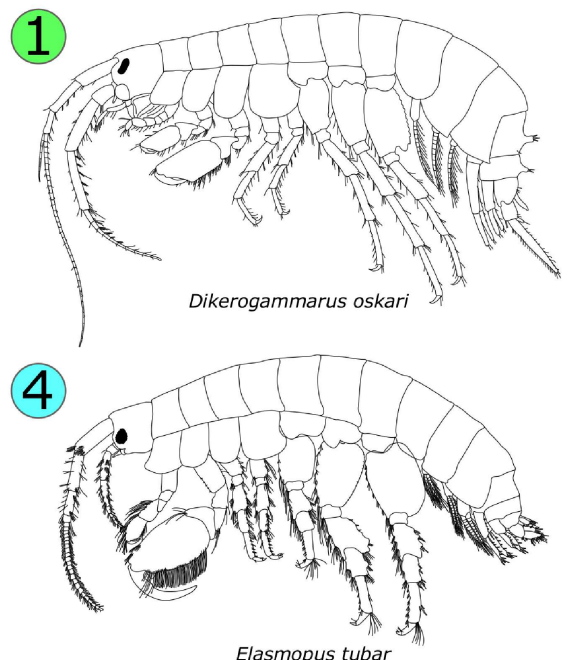

Fig. 7 Putative examples of ecomorphological convergence of Ponto-Caspian and distantly related oceanic taxa. Ponto-Caspian species are shown with green. a) Symbiotic ecomorph adapted to piercing various organic substrates (redrawn from Derzhavin (1948) and Loerz et al. (2010)), b) digger ecomorph adapted for digging and burrowing in fine substrates (redrawn from Sars (1895) and Barnard (1967)), c) clinger ecomorph adapted to cling on algal and vegetal substrates (redrawn from Sars (1896)), and d) crawler ecomorph adapted to a generalist life-style, usually hiding in coarse stony substrates (redrawn from (Sars (1896) and Garcia-Madrigal (2010)). The phylogenetic tree is a time-calibrated molecular phylogeny of Amphipoda modified after CopilaşCiocianu et al. (2020) 
We propose that the ecological and morphological diversity of Ponto-Caspian gammarids can be distilled into four ecomorphs. Remarkably, all of them apparently have analogues in distantly related lineages inhabiting oceanic waters or other ancient lakes (Figs. 7-8). The Ponto-Caspian symbiotic ecomorph is the most specialized and morphologically distinct due to its reduced mouthparts, antennae, pereopods and urosome, presumably due to a semi-parasitic life-style. We highlight a striking resemblance between the Ponto-Caspian genus Behningiella and the oceanic algae-boring genus Bircenna Chilton, 1884 (Fig. 7a). Both exhibit typical features for substrate boring such as a large head with protruding mandibles adapted to cutting into tough material, and extremely short antennae and pereopods due to living in narrow self-constructed tunnels (Mejaes et al. 2015). Within the Baikal Lake Acanthogammaride radiation, the symbiotic ecomorph is probably represented by the parasitic genus Pachyschesis (Naumenko et al. 2017; Takhteev 2019).

The fossorial ecomorph seems to be the most common among Ponto-Caspian amphipods. These species are generally adapted for digging in fine substrates and have stout, strong bodies with very short yet powerful and thick antennae, and broadened pereopods usually fringed with dense rows of setae. This ecomorph is widely encountered among amphipods in general, albeit under slightly different iterations (Bousfield 1970). Morphologically, most fossorial amphipods are classified within the superfamily Haustorioidea (Lowry and Myers 2017). However, molecular phylogenies indicate that the fossorial body-type evolved multiple times independently (Copilaş-Ciocianu, Borko, et al. 2020; Hancock et al. 2020). A noticeable resemblance can be observed between the Ponto-Caspian genus Compactogammarus and the hyaloidean Proboscinotus Barnard, 1967 (Fig. 7b). Additionally, in Lake Baikal this ecomorph is possibly represented by the Micruropodidae radiation, comprising fossorial species living on fine substrate (Naumenko et al. 2017; Takhteev 2019).

The clinger ecomorph characterizes species with elaborate body armature/ornamentation and preference for living (plant) substrate. These species often have elongated and curved dactyls for improved grasping of the substrate. Given the exposed nature of their life-style, the armature might serve as protection against predators (Bollache et al. 2006; Copilaş-Ciocianu, Borza, et al. 2020) or, in combination with variegated coloration (as is often the case with armored taxa), may act as camouflage by disrupting the body contour (d'Udekem d'Acoz and Verheye 2017). We point out the high similarity among the Ponto-Caspian genus Amathillina and the oceanic algae-clinging Gammarellus Herbst, 1793 (Fig. 7c). Although the Ponto-Caspian clingers are diverse in ornamentation and armature, some striking resemblance can be observed with Baikal Lake taxa. For example Amathillina and Eucarinogammarus (Baikal), Axelboeckia and Acanthogammarus (Baikal), and Kuzmelina and Propachygammarus (Baikal) (Naumenko et al. 2017; Takhteev 2019).

The crawler ecomorph is the second-most encountered in Ponto-Caspian amphipods, characterizing species living on coarse or fine substrate, often in shallow water. Typically, these taxa are strongly sexually dimorphic, males possessing very large second gnathopods, relatively long antennae and slender bodies with shallow coxal plates. Morphologically, this morph is probably the most plesiomorphic, being widespread among the amphipod evolutionary tree, especially in some basal branches (Copilaş-Ciocianu, Borko, et al. 2020; Lowry and Myers 2017) as well as in the oldest known fossils (Jarzembowski et al. 2020). As an example, we emphasize the similarity among the PontoCaspian genus Dikerogammarus and the widespread littoral genus Elasmopus Costa, 1853 (Fig. 7d).The Baikalian analogues of this ecomorph could be envisioned in Eulimnogammarus and Corophiomorphus (Naumenko et al. 2017; Takhteev 2019).

Body armature is extremely diverse in amphipods, with similar phenotypes having evolved independently multiple times (Copilaş-Ciocianu, Borko, et al. 2020; Lowry and Myers 2017; Naumenko et al. 2017). We highlight a remarkably convergent evolution of body armature in some ancient lake radiations where strong lateral spines appear on the pereonites, the longest one being 
located on the $4^{\text {th }}$ or $5^{\text {th }}$ segment (Fig. 8). In some cases the spine is an outgrowth of the tergum, while in others an outgrowth of the coxal plate. These analogous convergent structures point towards a strong selective pressure. Most likely these spines function as a mechanism for deterring ingestion by predatory fish (Bollache et al. 2006; Copilaş-Ciocianu, Borza, et al. 2020), although the exact mechanical interactions are unknown.

a

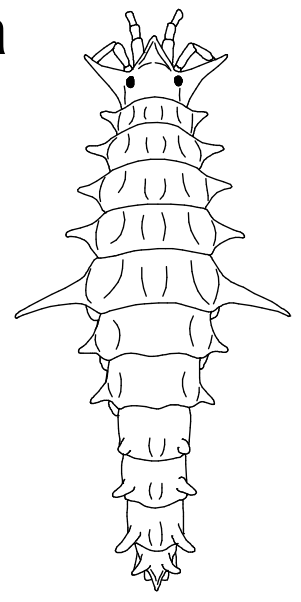

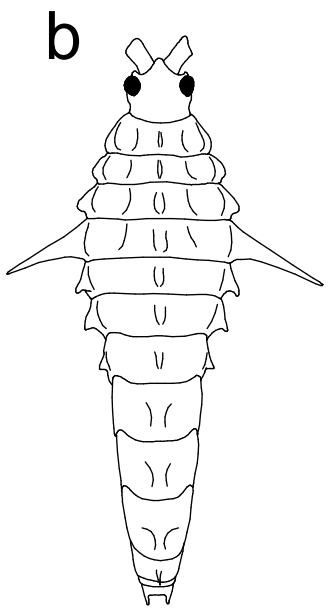
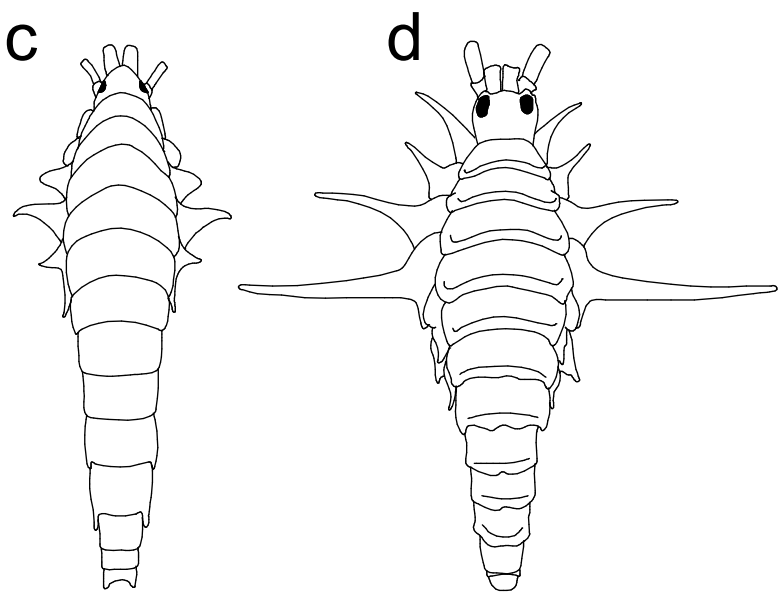

Fig. 8 Examples of evolutionary convergent patterns in body armature of species inhabiting different ancient lakes. a) Axelboeckia spinosa (Caspian Sea, redrawn after Sars (1894b)), b) Acanthogammarus lappaceus (Lake Baikal, redrawn after Daneliya et al. (2011)), c) Issykogammarus hamatus (Lake Issyk-Kul, redrawn after Chevreux (1908)), and d) Hyalella armata (Lake Titicaca, redrawn after González \& Coleman (2002))

\section{Spatio-temporal origin}

The phylogenetic position of Ponto-Caspian amphipods within the Atlanto-Mediterranean Echinogammarus clade (sensu Hou et al., 2014; Sket \& Hou, 2018) indicates that this radiation likely has a Mediterranean origin. Specifically, its sister clade is represented by the genus Dinarogammarus, which is endemic to freshwaters of the Western Balkans (Sket and Hou 2018). Regarding the temporal time-frame, several recent studies proposed a Middle Miocene origin (ca.12-14 Ma) (Copilaş-Ciocianu, Borko, et al. 2020; Hou and Sket 2016), coeval with the final closure of the Paratethys, which caused a switch from marine to brackish conditions and promoted the evolution of endemic faunas after initial mass extinctions (Popov et al. 2004; Rögl 1999). This time frame is also supported by Late Miocene (ca. 9-10 Ma) Caucasian fossil taxa (two genera and five species) that have clear affinities with extant Ponto-Caspian genera Axelboeckia, Gmelina, Kuzmelina and Yogmelina (Derzhavin 1927, 1941). Alternatively, an earlier study suggested an origin dating back to the Eocene (30-40 Ma) (Hou et al. 2014). However, this analysis was based on biogeographical calibration of the molecular clock rather than fossils, thus possibly resulting in biased inferences (Ho et al. 2015). Furthermore, a Late Eocene origin does not correspond with an isolation of the Paratethys realm from the world ocean (Popov et al. 2004). As such, we consider that a middle Miocene origin is more plausible considering the data at hand.

A densely sampled, multilocus and time-calibrated phylogeny will be of critical importance in understanding the historical biogeography and evolution of Ponto-Caspian gammarids. Furthermore, such a phylogeny could complement geological studies regarding the palaeogeographic history of the Paratethyan region, as seen with other freshwater gammarids (Copilaș-Ciocianu et al. 2019; CopilașCiocianu and Petrusek 2017; Hou et al. 2011; Mamos et al. 2016). It could provide additional time constraints on some important palaeogeographic events such as the final Paratethys closure, the 
isolation of the Pannonian, Pontic and Caspian basins, the emergence of the Caucasus, as well as the recurrent episodic connections of the Pontic and Caspian basins during the Plio-Pleistocene.

\section{Taxonomic and systematic remarks}

The Ponto-Caspian gammaroid amphipods as defined in this study are formally split into 5 families: Behningiellidae, Caspicolidae, Gammaridae, Iphigenellidae and Pontogammaridae. However, molecular research has revealed that Pontogammaridae is nested within Gammaridae, and also harbors the gammarid genus Dikerogammarus (Copilaş-Ciocianu, Borko, et al. 2020; Hou et al. 2014). Members of this family correspond to the digger ecomorph, which probably evolved on more than one occasion. Moreover, the Ponto-Caspian "Gammaridae" form a paraphyletic grade at the base of Pontogammaridae (Sket and Hou 2018). A taxonomically more inclusive morphological and molecular study will clarify this issue, but most likely will not recover Pontogammaridae as monophyletic. However, for the sake of stability we do not propose any taxonomic changes until this issue is firmly resolved.

The remaining families Behningiellidae, Caspicolidae and Iphigenellidae are poorly known and have not yet been sequenced. Behningiellidae and Iphigenellidae have been classified into Gammaroidea based on a morphological cladistic analysis (Lowry and Myers 2013). However, the monotypic Caspicolidae is currently not recognized as part of Gammaroidea, but as a distinct superfamily (Caspicoloidea) within the infraorder Talitrida (Lowry and Myers 2013). This classification is erroneous because the authors mistakenly considered that the antenna I lacks an accessory flagellum (a defining character state of the infraorder Talitrida). Derzhavin's (1944) original description clearly indicates the presence of the accessory flagellum, although it is reduced and uniarticulate. Another issue with assigning Caspicolidae to Talitrida is the presence of a well-developed mandibular palp, whereas an absent/vestigial palp is another defining character state of the Talitrida (Lowry and Myers 2013). Behningiellidae, Caspicolidae and Iphigenellidae belong to the symbiotic ecomorph and represent highly specialized taxa which are difficult to classify using external morphology alone. It is very likely that these small families are nothing but highly derived Ponto-Caspian gammarids, possibly related to the various genera of the gmelinid facies (Gmelina, Kuzmelina and Yogmelina) (Barnard and Barnard 1983; Bousfield 1977; Derzhavin 1944). Thus, the systematic position of these families will be clarified only with additional morphological and molecular study.

We argue that most, if not all Ponto-Caspian amphipod species are in need of thorough, modern revision using morphology, multilocus DNA sequences and ecology. Many species are only partially illustrated and intraspecific variability has been studied in only a handful of taxa (Cărăuşu 1936; Nahavandi et al. 2013). Moreover, cryptic lineages of potential specific status have been recently discovered (Jażdżewska et al. 2020). As such, a first step towards a modern taxonomic revision could be the generation of a well-sampled DNA barcode reference library.

Lastly, the Late-Miocene (Upper Sarmatian, ca. $9 \mathrm{Ma}$ ) fossil genera Andrussovia and Praegmelina have long been considered ancestral to extant Ponto-Caspian genera such as Gmelina and Amathillina, albeit without a formal analysis (Barnard and Barnard 1983; Derzhavin 1927, 1941). The fossils were discovered in calcareous clay deposits at the foothills of the Caucasus near Grozny, Solenaya balka (Chechnya, Russian Federation) and from Eldar Oyugu Ridge (Azerbaijan). We agree that there are rather clear affinities with extant Ponto-Caspian species in general, mainly in the combination of the following traits: shape of the basis of pereopod 7, ornamentation and armature, short and thick antennae, and deep coxal plates. Some traits are considered plesiomorphic, such as the lack of a postero-ventral lobe on the basis of pereopod 7, and the long endopod of uropod 3. A cladistic analysis is necessary to confidently assess evolutionary relationships with extant taxa. Until then, these species should be conservatively treated as stem Ponto-Caspian amphipods (CopilaşCiocianu, Borko, et al. 2020). 
Two more Miocene fossil taxa have been reported from the Caucasus that have less clear affinity with extant Ponto-Caspian taxa. These are Gammarus praecyrius, Derzhavin, 1941 and Hellenis saltatorius, Petunnikoff, 1914. The former is indistinguishable from a typical Gammarus and it is thus not considered a Ponto-Caspian taxon. The affinities of the latter taxon are less straightforward to interpret due to its high degree of morphological specialization (very short antennae, large raptorial gnathopods and unusually long pereopods). Such a combination of traits is not present in the extant Ponto-Caspian fauna. Furthermore, Petunnikoff's illustrations are also not detailed enough to draw a conclusion. At the moment we consider that it is possible that $H$. saltatorius could be related to Ponto-Caspian amphipods but further detailed studies are needed.

\section{Conclusion}

The Ponto-Caspian gammarid radiation fulfills, at least partially, the most important criteria of an adaptive radiation: 1) apparent monophyly, 2) sympatric occurrence within a constrained area, 3) accelerated diversification and 4) ecomorphological disparity. Nevertheless, these literature-based results are only preliminary and a lot of in depth eco-evolutionary study is further needed. Moreover, most species need a modern taxonomic revision within an evolutionary context. Nevertheless, we consider that Ponto-Caspian amphipods could be an excellent future model for the study of adaptive radiation, origin of invasive species, and could even help illuminate the region's dynamic palaeogeographic history.

\section{References}

Adamowicz, S. J., Marinone, M. C., Menu-Marque, S., Martin, J. W., Allen, D. C., Pyle, M. N., et al. (2018). The Hyalella (Crustacea: Amphipoda) species cloud of the ancient Lake Titicaca originated from multiple colonizations. Molecular Phylogenetics and Evolution, 125, 232-242. doi:10.1016/j.ympev.2018.03.004

Adrian-Kalchhauser, I., Blomberg, A., Larsson, T., Musilova, Z., Peart, C. R., Pippel, M., et al. (2020). The round goby genome provides insights into mechanisms that may facilitate biological invasions. BMC Biology, 18(1), 1-33. doi:10.1186/s12915-019-0731-8

Arbačiauskas, K., Lesutiene, J., \& Gasiunaite, Z. R. (2013). Feeding strategies and elemental composition in Ponto-Caspian peracaridans from contrasting environments: Can stoichiometric plasticity promote invasion success? Freshwater Biology, 58(5), 1052-1068. doi:10.1111/fwb.12108

Audzijonyte, A., Baltrunaite, L., Väinölä, R., \& Arbačiauskas, K. (2015). Migration and isolation during the turbulent Ponto-Caspian Pleistocene create high diversity in the crustacean Paramysis lacustris. Molecular Ecology, 24(17), 4537-4555. doi:10.1111/mec.13333

Barnard, J. L. (1958). Index to the families, genera and species of the gammaridean Amphipoda (Crustacea). Occasional Papers of the Allan Hancock Foundation, 19, 1-145.

Barnard, J. L. (1967). New and old dogielinotid marine Amphipoda. Crustaceana, 13, 281-291.

Barnard, J. L., \& Barnard, C. M. (1983). Freshwater Amphipoda of the World. Mt. Vernon, Virginia: Hayfield Associates.

Birstein, J. A., \& Romanova, N. N. (1968). Amphipoda. In J. A. Birstein, L. G. Vinogradova, \& N. N. Kondakova (Eds.), Atlas bespozvonochnykh Kaspiiskogo morya (pp. 241-289). Moscow: Pishevaya Promyshlennost Publ.

Birstein, J. A., Vinogradov, L. G., Kondakov, N. N., Kun, M. .., Astakhova, T. V., \& Romanova, N. N. (1968). Atlas bespozvonochnykh Kaspiiskogo morya (Atlas of Invertebrates of the Caspian Sea). Moscow: Pishevaya Promyshlennost Publ.

Bollache, L. İ., Kaldonski, N., Troussard, J. P., Lagrue, C., \& Rigaud, T. (2006). Spines and behaviour as defences against fish predators in an invasive freshwater amphipod. Animal Behaviour, 72(3), 627-633. doi:10.1016/j.anbehav.2005.11.020

Bousfield, E. L. (1970). Adaptive Radiation in Sand-burrowing Amphipod Crustaceans. Chesapeake 
Science, 11(3), 143-154.

Bousfield, E. L. (1977). A New Look at the Systematics of Gammaroidean Amphipods of the World. Crustaceana, 4(4), 282-316. doi:10.2307/25027471

Cărăuşu, S. (1936). Etude sue le Pontogammarus maeoticus (Sow.) Mart. Annales Scientifique de I'Universite de Jassy, 13(1-4), 133-156.

Cărăuşu, S. (1943). Amphipodes de Roumanie I. Gammarides de type Caspian. Bucharest: Institutul de Cercetari Piscicole al Romaniei.

Cărăuşu, S., Dobreanu, E., \& Manolache, C. (1955). Fauna Republicii Populare Romîne. Crustacea. Amphipoda Forme Salmastre şi de Apă Dulce. Bucharest: Editura Academiei RPR.

Chertoprud, E. S., Sokolova, A. M., \& Garlitska, L. A. (2018). Harpacticoida (Copepoda) of the Caspian Sea: Faunistics, ecology and biogeography. Journal of Experimental Marine Biology and Ecology, 502, 63-70. doi:10.1016/j.jembe.2017.03.011

Chevreux, E. (1908). Études sur la faune du Turkestan basées sur les matériaux recueillis par D.D. Pedaschenko (1904-1906). In II. Crustacés Amphipodes (pp. 91-110).

Copilaş-Ciocianu, D., Borko, Š., \& Fišer, C. (2020). The late blooming amphipods: Global change promoted post-Jurassic ecological radiation despite Palaeozoic origin. Molecular Phylogenetics and Evolution, 143(October 2019), 106664. doi:10.1016/j.ympev.2019.106664

Copilaş-Ciocianu, D., Borza, P., \& Petrusek, A. (2020). Extensive variation in the morphological antipredator defense mechanism of Gammarus roeselii Gervais, 1835 (Crustacea:Amphipoda). Freshwater Science, 39(1), 47-55. doi:10.1086/707259

Copilaș-Ciocianu, D., \& Petrusek, A. (2015). The southwestern Carpathians as an ancient centre of diversity of freshwater gammarid amphipods: Insights from the Gammarus fossarum species complex. Molecular Ecology, 24(15), 3980-3992. doi:10.1111/mec.13286

Copilaș-Ciocianu, D., \& Petrusek, A. (2017). Phylogeography of a freshwater crustacean species complex reflects a long-gone archipelago. Journal of Biogeography, 44, 421-432. doi:10.1111/jbi.12853

Copilaș-Ciocianu, D., Sidorov, D. A., \& Gontcharov, A. A. (2019). Adrift across tectonic plates: molecular phylogenetics supports the ancient Laurasian origin of old limnic crangonyctid amphipods. Organisms Diversity \& Evolution, 19, 191-207. doi:10.1007/s13127-019-00401-7

Cristescu, M. E. A., \& Hebert, P. D. N. (2005). The "Crustacean Seas" - an evolutionary perspective on the Ponto-Caspian peracarids. Canadian Journal of Fisheries and Aquatic Sciences, 62(3), 505-517. doi:10.1139/f04-210

Cristescu, M. E. A., Witt, J. D. S., Grigorovich, I. A., Hebert, P. D. N., \& Maclsaac, H. J. (2004). Dispersal of the Ponto-Caspian amphipod Echinogammarus ischnus: invasion waves from the Pleistocene to the present. Heredity, 92(3), 197-203. doi:10.1038/sj.hdy.6800395

Cristescu, M. E., Adamowicz, S. J., Vaillant, J. J., \& Haffner, D. G. (2010). Ancient lakes revisited: From the ecology to the genetics of speciation. Molecular Ecology, 19(22), 4837-4851. doi:10.1111/j.1365-294X.2010.04832.x

Cuthbert, R. N., Kotronaki, S. G., Dick, J. T. A., \& Briski, E. (2020). Salinity tolerance and geographical origin predict global alien amphipod invasions. Biology Letters, 16(9), 2-7. doi:10.1098/rsbl.2020.0354

d'Udekem d'Acoz, C., \& Verheye, M. L. (2017). Epimeria of the Southern Ocean with notes on their relatives (Crustacea, Amphipoda, Eusiroidea). European Journal of Taxonomy, 359, 1-553. doi:10.5852/ejt.2017.359

Daneliya, M. E., Kamaltynov, R. M., \& Väinölä, R. (2011). Phylogeography and systematics of Acanthogammarus s. str., giant amphipod crustaceans from Lake Baikal. Zoologica Scripta, 40(6), 623-637. doi:10.1111/j.1463-6409.2011.00490.x

Derzhavin, A. N. (1927). Notes on the Upper Sarmatian Amphipods of the Ponto-Caspian region. Bulletin de la Societe des Naturalistes de Moscou, 2, 183-196.

Derzhavin, A. N. (1941). Iskolaemyye bokoplavii Eldara. Izvestyia Azerbaidzhanskogo Filiala Akademii nauk SSSR, (2), 65-69.

Derzhavin, A. N. (1944). A new family Caspiellidae from the Caspian Sea. Bulletin of the Azerbaijan 
Filiation of the Academy of Sciences of the USSR, 8, 20-24.

Derzhavin, A. N. (1948). Novye formy gammarid iz Kaspiiskogo Morya. In Pamiaty akademika Sergeia Aleksandrovicha Zernova (pp. 280-286). Moscow: USSR Academy of Sciences Publishing House. Dumont, H. (1995). Ecocide in the Caspian sea. Nature, 377(6551), 673-674. doi:10.1038/377673a0 Fišer, C., Trontelj, P., Luštrik, R., \& Sket, B. (2009). Toward a unified taxonomy of Niphargus (Crustacea: Amphipoda): a review of morphological variability. Zootaxa, 2061, 1-22.

Garcia-Madrigal, M. S. (2010). Littoral Maeridae and Melitidae (Amphipoda: Gammaridea) from the Gulf of Tehuantepec, Mexico. Zootaxa, 2623, 1-51.

Gogaladze, A., Raes, N., Biesmeijer, J. C., Ionescu, C., Pavel, A. B., Son, M. O., et al. (2020). Social network analysis and the implications for Pontocaspian biodiversity conservation in Romania and Ukraine: A comparative study. PLOS ONE, 15(10 October), 1-20. doi:10.1371/journal.pone.0221833

González, E. R., \& Coleman, C. O. (2002). Hyalella armata (Crustacea, Amphipoda, Hyalellidae) and the description of a related new species from Lake Titicaca. Organisms Diversity and Evolution, 2(3), 271-273. doi:10.1078/1439-6092-00047

Grabowski, M., Bacela, K., \& Konopacka, A. (2007). How to be an invasive gammarid (Amphipoda: Gammaroidea) - Comparison of life history traits. Hydrobiologia, 590(1), 75-84. doi:10.1007/s10750-007-0759-6

Hancock, Z. B., Ogawa, H., Light, J. E., \& Wicksten, M. K. (2020). Origin and evolution of the Haustoriidae (Amphipoda): A eulogy for the Haustoriidira. bioRxiv. doi:10.1101/2020.10.24.353664

Ho, S. Y. W., Tong, K. J., Foster, C. S. P., Ritchie, A. M., Lo, N., \& Crisp, M. D. (2015). Biogeographic calibrations for the molecular clock. Biology Letters, 11(9). doi:10.1098/rsbl.2015.0194

Horton, T., Lowry, J., De Broyer, C., Bellan-Santini, D. Coleman, C. O., Corbari, L., Costello, M. J. Daneliya, M., et al. (2020). World Amphipoda Database. Accessed at http://www.marinespecies.org/amphipoda on 2020-11-10. doi:10.14284/368. http://www.marinespecies.org/amphipoda. Accessed 29 March 2019

Hou, Z., \& Sket, B. (2016). A review of Gammaridae (Crustacea: Amphipoda): The family extent, its evolutionary history, and taxonomic redefinition of genera. Zoological Journal of the Linnean Society, 176(2), 323-348. doi:10.1111/zoj.12318

Hou, Z., Sket, B., Fišer, C., \& Li, S. (2011). Eocene habitat shift from saline to freshwater promoted Tethyan amphipod diversification. Proceedings of the National Academy of Sciences of the United States of America, 108(35), 14533-14538. doi:10.1073/pnas.1104636108

Hou, Z., Sket, B., \& Li, S. (2014). Phylogenetic analyses of Gammaridae crustacean reveal different diversification patterns among sister lineages in the Tethyan region. Cladistics, 30(4), 352-365. doi:10.1111/cla.12055

Jarzembowski, E. A., Chény, C., Fang, Y., \& Wang, B. (2020). First Mesozoic amphipod crustacean from the Lower Cretaceous of SE England. Cretaceous Research, 112, 104429. doi:10.1016/j.cretres.2020.104429

Jażdżewska, A. M., Rewicz, T., Mamos, T., Wattier, R., Bącela-Spychalska, K., \& Grabowski, M. (2020). Cryptic diversity and mtDNA phylogeography of the invasive demon shrimp, Dikerogammarus haemobaphes (Eichwald, 1841), in Europe. NeoBiota, 57, 53-86. doi:10.3897/neobiota.57.46699

Jurado-Rivera, J. A., Zapelloni, F., Pons, J., Juan, C., \& Jaume, D. (2020). Morphological and molecular species boundaries in the Hyalella species flock of Lake Titicaca (Crustacea: Amphipoda). Contributions to Zoology, 89(4), 353-372. doi:10.1163/18759866-bja10004

Karaman, G. S., \& Pinkster, S. (1977). Freshwater Gammarus species from Europe, North Africa and adjacent regions of Asia (Crustacea-Amphipoda). Part I Gammarus pulex-group and related species. Bijdragen Tot De Dierkunde, 47, 1-97.

Katouzian, A.-R., Sari, A., Macher, J. N., Weiss, M., Saboori, A., Leese, F., \& Weigand, A. M. (2016). Drastic underestimation of amphipod biodiversity in the endangered Irano-Anatolian and Caucasus biodiversity hotspots. Scientific Reports, 6(1), 22507. doi:10.1038/srep22507 
Krijgsman, W., Tesakov, A., Yanina, T., Lazarev, S., Danukalova, G., Van Baak, C. G. C., et al. (2019). Quaternary time scales for the Pontocaspian domain: Interbasinal connectivity and faunal evolution. Earth-Science Reviews, 188(October 2018), 1-40. doi:10.1016/j.earscirev.2018.10.013

Lattuada, M., Albrecht, C., \& Wilke, T. (2019). Differential impact of anthropogenic pressures on Caspian Sea ecoregions. Marine Pollution Bulletin, 142, 274-281. doi:10.1016/j.marpolbul.2019.03.046

Loerz, A. N., Kilgallen, N. M., \& Thiel, M. (2010). Algal-dwelling Eophliantidae (Amphipoda): description of a new species and key to the world species, with notes on their biogeography. Journal of the Marine Biological Association of the United Kingdom, 90(5), 1055-1063.

Lowry, J. K., \& Myers, A. A. (2013). A Phylogeny and Classification of the Senticaudata subord. nov. (Crustacea: Amphipoda). Zootaxa, 3610(1), 1-80. doi:10.11646/zootaxa.3610.1.1

Lowry, J. K., \& Myers, A. A. (2017). A Phylogeny and Classification of the Amphipoda with the establishment of the new order Ingolfiellida (Crustacea: Peracarida). Zootaxa, 4265(1), 1-89. doi:10.11646/zootaxa.4265.1.1

Macdonald, K. S., Yampolsky, L., \& Duffy, J. E. (2005). Molecular and morphological evolution of the amphipod radiation of Lake Baikal. Molecular Phylogenetics and Evolution, 35(2), 323-343. doi:10.1016/j.ympev.2005.01.013

MacNeil, C., Dick, J., \& Elwood, R. (1997). The trophic ecology of freshwater Gammarus spp. (Crustacea: Amphipoda): problems and perspectives concerning the functional feeding group concept. Biological Reviews, 72, 349-364. https://www.cambridge.org/core/journals/biologicalreviews/article/trophic-ecology-of-freshwater-gammarus-spp-crustacea-amphipoda-problemsand-perspectives-concerning-the-functional-feeding-groupconcept/20499173A4878B0DF607A797CBE32671

Mamos, T., Wattier, R., Burzynski, A., \& Grabowski, M. (2016). The legacy of a vanished sea: A high level of diversification within a European freshwater amphipod species complex driven by 15 My of Paratethys regression. Molecular Ecology, 25(3), 795-810. doi:10.1111/mec.13499

Mamos, T., Wattier, R., Majda, A., Sket, B., \& Grabowski, M. (2014). Morphological vs. molecular delineation of taxa across montane regions in Europe: The case study of Gammarus balcanicus Schaferna, (Crustacea: Amphipoda). Journal of Zoological Systematics and Evolutionary Research, 52(3), 237-248. doi:10.1111/jzs.12062

Martens, K. (1997). Speciation in ancient lakes. Trends in Ecology and Evolution, 12(5), 177-182. doi:10.1016/S0169-5347(97)01039-2

Martens, K., \& Schön, I. (1999). Crustacean Biodiversity in Ancient Lakes : A Review. Crustaceana, 72(8), 899-910.

Martynov, A. V. (1930). Fauna Amphipoda Teletskogo ozera I ee proiskhozhdenie. Izv. Gosud. Gidrob. Inst., 29, 95-128.

Mejaes, A. B., Poore, A. G. B., \& Thiel, M. (2015). Crustaceans inhabiting domiciles excavated from macrophytes and stone. In The Natural History of the Crustacea, Volume 2. Lifestyles and Feeding Biology (pp. 118-144). New York: Oxford University Press.

Mordukhai-Boltovskoi. (1964). Caspian Fauna Beyond the Caspian Sea. Internationale Revue der gesamten Hydrobiologie und Hydrographie, 49(1), 139-176. doi:10.1002/iroh.19640490105

Mordukhai-Boltovskoi, P. D. (1979). Composition and Distribution of Caspian Fauna in the Light of Modern Data. Internationale Revue der gesamten Hydrobiologie und Hydrographie, 64(1), 1-38. doi:10.1002/iroh.19790640102

Nahavandi, N., Ketmaier, V., Plath, M., \& Tiedemann, R. (2013). Diversification of Ponto-Caspian aquatic fauna: Morphology and molecules retrieve congruent evolutionary relationships in Pontogammarus maeoticus (Amphipoda: Pontogammaridae). Molecular Phylogenetics and Evolution, 69(3), 1063-1076. doi:10.1016/j.ympev.2013.05.021

Naseka, A. M., \& Bogutskaya, N. G. (2009). Fishes of the Caspian Sea: zoogeography and updated check-list. Zoosystematica Rossica, 18(2), 295-317. doi:10.31610/zsr/2009.18.2.295

Naumenko, S. A., Logacheva, M. D., Popova, N. V., Klepikova, A. V., Penin, A. A., Bazykin, G. A., et al. 
(2017). Transcriptome-based phylogeny of endemic Lake Baikal amphipod species flock: fast speciation accompanied by frequent episodes of positive selection. Molecular Ecology, 26(2), 536-553. doi:10.1111/mec.13927

Palcu, D. V., Popov, S. V., Golovina, L. A., Kuiper, K. F., Liu, S., \& Krijgsman, W. (2019). The shutdown of an anoxic giant: Magnetostratigraphic dating of the end of the Maikop Sea. Gondwana Research, 67, 82-100. doi:10.1016/j.gr.2018.09.011

Pinkster, S. (1993). A revision of the genus Echinogammarus Stebbing, 1899 with some notes on related genera (Crustacea, Amphipoda). Memorie del Museo Civico di Storia Naturale, 10, 1185.

Piscart, C., Navel, S., Maazouzi, C., Montuelle, B., Cornut, J., Mermillod-Blondin, F., et al. (2011). Leaf litter recycling in benthic and hyporheic layers in agricultural streams with different types of land use. Science of the Total Environment, 409(20), 4373-4380. doi:10.1016/j.scitotenv.2011.06.060

Pjatakova, G. M., \& Tarasov, A. G. (1996). Caspian Sea amphipods: biodiversity, systematic position and ecological peculiarities of some species. International Journal of Salt Lake Research, 5(1), 63-79. doi:10.1007/BF01996036

Popov, S. V., Rögl, F., Rozanov, A. Y., Steininger, F. F., Shcherba, I. G., \& Kovac, M. (2004). Lithologicalpaleogeographic maps of Paratethys. CFS Courier Forschungsinstitut Senckenberg, 250, 1-46.

Prange, M., Wilke, T., \& Wesselingh, F. P. (2020). The other side of sea level change. Communications Earth \& Environment, 1, 69. doi:10.1038/s43247-020-00075-6

Reid, D. F., \& Orlova, M. I. (2002). Geological and evolutionary underpinnings for the success of Ponto-Caspian species invasions in the Baltic Sea and North American Great Lakes. Canadian Journal of Fisheries and Aquatic Sciences, 59(7), 1144-1158. doi:10.1139/f02-099

Rewicz, T., Wattier, R., Grabowski, M., Rigaud, T., \& Bacela-Spychalska, K. (2015). Out of the Black sea: Phylogeography of the invasive killer shrimp Dikerogammarus villosus across Europe. PLoS ONE, 10(2), 1-20. doi:10.1371/journal.pone.0118121

Rögl, F. (1999). Mediterranean and Paratethys. Facts and hypotheses of an Oligocene to Miocene paleogeography (short overview). Geologica Carpathica, 50(4), 339-349. http://www.nhmwien.ac.at/jart/prj3/nhm/data/uploads/mitarbeiter_dokumente/roegl/1999_Roegl_Palgeo_Ge olCarp.pdf

Salzburger, W., Bocxlaer, B. Van, \& Cohen, A. S. (2014). Ecology and evolution of the African great lakes and their faunas. Annual Review of Ecology, Evolution, and Systematics, 45, 519-545. doi:10.1146/annurev-ecolsys-120213-091804

Sars, G. O. (1894a). Crustacea caspia. Contributions to the knowledge of the Carcinological Fauna of the Caspian Sea. Part III. Amphipoda. Bulletin de l'Academie Imperiale des Sciences de St.Ptetersbourg, 1(2), 179-223.

Sars, G. O. (1894b). Crustacea caspia. Contributions to the knowledge of the Carcinological Fauna of the Caspian Sea. Part III. Amphipoda. Bulletin de l'Academie Imperiale des Sciences de St.Ptetersbourg, 1(4), 343-378.

Sars, G. O. (1895). Crustacea caspia. Contributions to the knowledge of the Carcinological Fauna of the Caspian Sea. Part III. Amphipoda. Bulletin de l'Academie Imperiale des Sciences de St.Ptetersbourg, 3(3), 275-314.

Sars, G. O. (1896). Crustacea caspia. Contributions to the knowledge of the Carcinological Fauna of the Caspian Sea. Bulletin de I'Academie Imperiale des Sciences de St.-Ptetersbourg, 4(5), 421489.

Schluter, D. (2000). The Ecology of Adaptive Radiation. Oxford: Oxford University Press.

Seehausen, O. (2015). Process and pattern in cichlid radiations - inferences for understanding unusually high rates of evolutionary diversification. New Phytologist, 207(2), 304-312. doi:10.1111/nph.13450

Simões, M., Breitkreuz, L., Alvarado, M., Baca, S., Cooper, J. C., Heins, L., et al. (2016). The Evolving Theory of Evolutionary Radiations. Trends in Ecology and Evolution, 31(1), 27-34. doi:10.1016/j.tree.2015.10.007 
Sket, B., \& Fišer, C. (2009). A new case of intralacustrine radiation in amphipoda. a new genus and three new species of Anisogammaridae (Crustacea, Amphipoda) from the ancient lake Fuxian Hu in Yunnan, China. Journal of Zoological Systematics and Evolutionary Research, 47(2), 115123. doi:10.1111/j.1439-0469.2008.00477.x

Sket, B., \& Hou, Z. (2018). Family Gammaridae (Crustacea: Amphipoda), mainly its Echinogammarus clade in SW Europe. Further elucidation of its phylogeny and taxonomy. Acta Biologica Slovenica, 61(1), 93-102.

Takhteev, V. V. (2019). On the current state of taxonomy of the Baikal Lake amphipods (Crustacea: Amphipoda) and the typological ways of constructing their system. Arthropoda Selecta, 28(3), 374-402. doi:10.15298/arthsel.28.3.03

Trontelj, P., Blejec, A., \& Fišer, C. (2012). Ecomorphological convergence of cave communities. Evolution, 66(12), 3852-3865. doi:10.1111/j.1558-5646.2012.01734.x

Väinölä, R., Vainio, J. K., \& Palo, J. U. (2001). Phylogeography of "glacial relict" Gammaracanthus (Crustacea, Amphipoda) from boreal lakes and the Caspian and White seas. Canadian Journal of Fisheries and Aquatic Sciences, 58, 2247-2257.

Väinölä, R., Witt, J. D. S., Grabowski, M., Bradbury, J. H., Jazdzewski, K., \& Sket, B. (2008). Global diversity of amphipods (Amphipoda; Crustacea) in freshwater. Hydrobiologia, 595(1), 241-255. doi:10.1007/s10750-007-9020-6

Vanderploeg, H. A., Nalepa, T. F., Jude, D. J., Mills, E. L., Holeck, K. T., Liebig, J. R., et al. (2002). Dispersal and emerging ecological impacts of Ponto-Caspian species in the Laurentian Great Lakes. Canadian Journal of Fisheries and Aquatic Sciences, 59(7), 1209-1228. doi:10.1139/f02087

Wellborn, G. A., \& Broughton, R. E. (2008). Diversification on an ecologically constrained adaptive landscape. Molecular Ecology, 17(12), 2927-2936. doi:10.1111/j.1365-294X.2008.03805.x

Wellborn, G. A., \& Langerhans, R. B. (2015). Ecological opportunity and the adaptive diversification of lineages. Ecology and Evolution, 5(1), 176-195. doi:10.1002/ece3.1347

Wesselingh, F. P., Neubauer, T. A., Anistratenko, V. V., Vinarski, M. V., Yanina, T., ter Poorten, J. J., et al. (2019). Mollusc species from the Pontocaspian region - an expert opinion list. ZooKeys, 2019(827), 31-124. doi:10.3897/zookeys.827.31365

Witt, J. D. S., Threloff, D. L., \& Hebert, P. D. N. (2006). DNA barcoding reveals extraordinary cryptic diversity in an amphipod genus: Implications for desert spring conservation. Molecular Ecology, 15(10), 3073-3082. doi:10.1111/j.1365-294X.2006.02999.x

Wysocka, A., Grabowski, M., Sworobowicz, L., Burzyński, A., Kilikowska, A., Kostoski, G., \& Sell, J. (2013). A tale of time and depth: Intralacustrine radiation in endemic Gammarus species flock from the ancient Lake Ohrid. Zoological Journal of the Linnean Society, 167(3), 345-359. doi:10.1111/j.1096-3642.2012.00878.x

Wysocka, A., Grabowski, M., Sworobowicz, L., Mamos, T., Burzyński, A., \& Sell, J. (2014). Origin of the Lake Ohrid gammarid species flock: Ancient local phylogenetic lineage diversification. Journal of Biogeography, 41(9), 1758-1768. doi:10.1111/jbi.12335 
bioRxiv preprint doi: https://doi.org/10.1101/2021.01.21.427559; this version posted January 21, 2021. The copyright holder for this preprint (which was not certified by peer review) is the author/funder, who has granted bioRxiv a license to display the preprint in perpetuity. It is made available under aCC-BY-NC-ND 4.0 International license. 
881

882

883

884

885

886

887

888

889

890

891

892

893

894

895

896

897

898

899

900

901

902

903

904

905

906

907

908

909

910

911

912

913

914

915

916

917

918

919

920

921

922

923

924

925

926

927

928

929

930

931

\section{Appendix}

Key to endemic families, genera and species of Ponto-Caspian amphipods (including nonGammaroidea).

Key to families (parentheses indicate non-Gammaroid genera that contain more than one species; their species are keyed in the "Key to species" below)

1. Eyes absent Niphargidae

- Eyes present 2

2. Body dorso-ventrally compressed, coxal plates rudimentary, antenna 2 greatly developed Corophiidae (Chelicorophium)

- Body laterally compressed, coxal plates developed, antenna 2 normally developed 3

3. Head rostrum long and narrow, uropod 3 rami foliaceous of equal length ......... Gammaracanthidae

- Head rostrum absent or rudimentary, uropod 3 rami slender, subequal ...

4. Telson uncleft Uristidae (Onisimus)

- Telson cleft Pontoporeiidae

5. Pereopod 6 much longer than pereopods 5 and 6

- Pereopod as long as or slightly longer than pereopods 5 and 6 Caspicolidae

6. Gnathopods chelate... Iphigenellidae

7. Pereopods 5-7 prehensile Iphigenellidae

- Pereopods 5-7 not prehensile 8 8. Maxilliped and mandibular palp reduced, and/or meral articles of pereopod $5-7$ with postero-dista
lobe ................................................................................................................. Behningiellidae - Maxilliped and mandibular palp normal, meral articles of pereopod 5-7 without postero-distal lobe 9. Antenna 1 peduncle article 1 slender, as long as or shorter than articles 2 and 3 combined Gammaridae - Antenna 1 peduncle article 1 swollen, longer than articles 2 and 3 combined Pontogammaridae

\section{Key to genera (only Gammaroidea)}

1. Gnathopods chelate.

- Gnathopods subchelate (monotypic: Caspicola knipovitschi Derzhavin, 1945)

2. Head with lateral projections ... 2

- Head without lateral projections 3

3. Strong lateral-pointing spine on pereonite 5

Axelboeckia

- No spines, only blunt knobs on pereonite 5

(monotypic: Axelboeckia spinosa (G.O. Sars, 1894))

4. Body with two dorso-lateral rows of knobs

Kuzmelina

(monotypic: Kuzmelina kusnezowi (Sowinsky, 1894))

- Body with a central dorsal a keel on pereonal segments 6-7 and pleosome Gmelinopsis

5. Antenna 1 accessory flagellum uniarticulate 6

- Antenna 1 accessory flagellum two- or multiarticulated .. 10

6. Lateral head lobes form a characteristic "hood" Scytaelina

- Lateral head lobes normal

(monotypic: Scytaelina simplex Stock et al., 1998)

7. Bases of pereopods 5-6 lobed, uropod 3 reduced Behningiella

(monotypic: Behningiella brachypus Derzhavin, 1948)

- Bases of pereopods 5-6 not lobed, uropod 3 normal 8

8. Body with an obvious central dorsal keel, more pronounced on the pleosome Gmelina

- Body with a weak or absent central dorsal keel 
- Antenna 1 peduncle article 3 shorter than article 1

(monotypic: Sowinskya macrocera Derzhavin, 1948)

17. Uropod 3 setae curled, longer than spines

Trichogammarus

- Uropod 3 setae straight, shorter than spines

(monotypic: Trichogammarus trichiatus (Martynov, 1932))

18. Pereopod 6 basis lobed

Chaetogammarus

- Pereopod 6 basis not lobed 19

19. Pereopod 5-7 meral articles with a postero-distal lobe

Zernovia

(monotypic: Zernovia volgensis Derzhavin, 1948)

- Pereopod 5-7 meral articles without a postero-distal lobe

Shablogammarus

(monotypic: Shablogammarus shablensis (Cărăușu, 1943))

20. Antenna 1 flagellum shorter than peduncle ..... 21

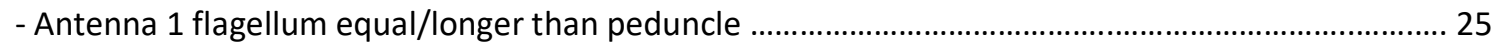

21. Epimeron 3 with postero-ventral setal fan

22. Uropod 3 endopod longer than half of exopod

(monotypic: Uroniphargoides spinicaudatus (Cărăușu, 1943))

- Uropod 3 endopod shorter than half of exopod

23. Ganthopod 2 propodus palm longer than posterior margin ............................. Compactogammarus
(monotypic: Compactogammarus compactus (G.O. Sars, 1895))

- Ganthopod 2 propodus palm shorter than posterior margin

Niphargoides

24. Uropod 3 exopod $2^{\text {nd }}$ article well developed, bearing lateral setae

- Uropod 3 exopod $2^{\text {nd }}$ article minute/absent, bearing no lateral setae Niphargogammarus

25 . Eyes round to ovoid, gnathopod 2 propodus large and triangular, armed with a palmar spine as long as $1 / 3$ of dactylus

- Eyes reniform, gnathopod 2 propodus armed with a palmar spine(s) shorter than $1 / 3$ of dactylus

26. Antenna 1 peduncular article 1 slender, width not exceeding $1 / 3$ of length, pereopods 3-4 with sparse setae shorter than the width of underlying segment ....

- Antenna 1 peduncular article 1 robust, width exceeding 1/3 of length, pereopods $3-4$ with dense setae as long as/longer than the width of underlying segment (except $O$. subnudus) .. 30 27. Body with a central dorsal a keel . 
28. Head swollen and enlarged

- Head normal

29. Urosomites 1-2 with columnar tubercles

Dikerogammarus

- Urosomites 1-2 without columnar tubercles

Akerogammarus

30. Uropod 3 exopod $2^{\text {nd }}$ article at least $1 / 5$ the length of $1^{\text {st }}$ article

- Uropod 3 exopod $2^{\text {nd }}$ article much shorter than $1 / 5$ the length of $1^{\text {st }}$ article

31. Uropod 3 exopod outer margin armed with few simple setae Stenogammarus - Uropod 3 exopod outer margin armed with many plumose setae Wolgagammarus (monotypic: Wolgagammarus dzjubani (Mordukhai-Boltovskoi \& Ljakhov, 1972)) 32. Setae on posterior margin of carpal articles of pereopods 3-4 arranged in a continuous fan

Pontogammarus

- Setae on posterior margin of carpal articles of pereopods 3-4 arranged in clusters 33

33. Urosomites 1-2 with noticeable dorsal knobs Turcogammarus - Urosomites 1-2 flat or humped Obesogammarus

\section{Key to species}

Doubtful species are indicated with an asterisk (*).

\section{Key to species of Akerogammarus}

1. Propodi of gnathopods 1 and 2 similar in size, telson with short apical setae A. contiguous

- Propodus of gnathopod 2 larger than gnathopod 1, telson with long apical setae ..... A. knipowitschi

\section{Key to species of Amathillina}

1. Body keel starts from the first pereonite 2

- Body keel starts from the sixth pereonite or later A. spinosa

2. Pereonites 1-2 with well-developed dorsal spines, urosomite 1 humped A. cristata

- Pereonites 1-2 with barely visible crest, urosomite 1 not humped A. maximowiczi

3. Body keel present only on pleosome A. pussila

- Body keel present on pereonites 6-7 and pleosome A. affinis

4. Antenna 1 accessory flagellum bi-articulated, last pleonal projection rounded - Antenna 1 accessory flagellum tri-articulated, last pleonal projection triangular

Key to species of Cardiophilus

1. Uropod 3 exopod less than twice the length of peduncle, $2^{\text {nd }}$ article present C. baeri - Uropod 3 exopod twice the length of peduncle, $2^{\text {nd }}$ article absent C. maris-nigri

\section{Key to species of Chaetogammarus}

1. Antenna 1 accessory flagellum bi-articulated C. warpachowskyi

- Antenna 1 accessory flagellum at least three articles C. hyrcanus

2. Pleosome covered with small spines C. hyrcanus

- Pleosome bare C. placidus

3. Eyes very elongated and constricted in the middle .............. 4 - Eyes regular (reniform) C. ischnus

4. Antenna 1 and 2 set with dense setae longer than the underlying segment C. pauxillus

\section{Key to species of Chelicorophium}

1. Antenna 2 peduncular article 4 distal tooth simple C. monodon

- Antenna 2 peduncular article 4 distal tooth with an additional simple or bidentate tooth 
7. Antenna 2 peduncular article 5 proximal tooth situated in the distal half of the article, inner side of uropod 3 peduncle without spines

C. maeoticum - Antenna 2 peduncular article 5 proximal tooth situated in the proximal half of the article, inner side of uropod 3 peduncle with spines .. C. robustum

.. C. curvispinum

\section{Key to species of Derzhavinella}

1. Anterior margin of pereopod 7 with long setae

D. macrochelata

- Anterior margin of pereopod 7 with short setae D. cava

\section{Key to species of Dikerogammarus}

1. Pleosome segments keeled D. caspius

- Pleosome segments flat D. fluviatilis*

2. Urosomal tubercles low 3

- Urosomal tubercles columnar, well developed D. gruberi

3. Antenna 1 accessory flagellum bi-articulated

- Antenna 1 accessory flagellum 4 or more articles 4

4. Propodi of gnathopods $1 \& 2$ with mid-palmar spine D. aralychensis*

- Propodi of gnathopods $1 \& 2$ without mid-palmar spine 5

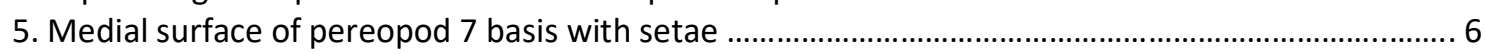

- Medial surface of pereopod 7 basis without setae .......................................................................... 7

6. Antenna 2 peduncular segments with numerous clusters of setae longer than the underlying segment ......

D. bispinosus

- Antenna 2 peduncular segments with few clusters of setae shorter than the underlying segment

7. Propodi of gnathopods $1 \& 2$ with setae as long as propodus width

D. istanbulensis

- Propodi of gnathopods $1 \& 2$ with setae much shorter than propodus width D. villosus

8. Uropod 3 exopod with spines on inner and outer margins D. haemobaphes

- Uropod 3 exopod without spines D. oskari

\section{Key to species of Gmelina}

1. Pleonal humps high and triangular

G. costata

- Pleonal humps low and rounded

G. aestuarica

\section{Key to species of Gmelinopsis}

1. Head lateral projections blunt, tubercle-like

G. tuberculata

- Head lateral projections pointed, spear-like G. aurita

\section{Key to species of Niphargogammarus}

1. Antenna 1 main flagellum as long as the first peduncular article 2

- Antenna 1 main flagellum shorter than the first peduncular article 3 
2. Body size ca. $10 \mathrm{~mm}$, gnathopod 2 propodus larger than gnathopod 1 , telson lobes diverging and armed with 1 apical spine N. quadrimanus - Body size ca. $5 \mathrm{~mm}$, propodi of both gnathopods similar in size, telson lobes not diverging and armed apically with 2 spines N. aequimanus 3. Body size ca. $13 \mathrm{~mm}$, urosomite 1 bare, uropod 3 exopod external margin armed with many setae N. borodini - Body size ca. $7 \mathrm{~mm}$, urosomite 1 armed with small setae, uropod 3 exopod external margin armed with few distal setae N. intermedius

\section{Key to species of Niphargoides}

1. Posterior margin of pereopod 6 basis armed with a few short setae proximally N. grimmi

- Posterior margin of pereopod 6 basis armed with long setae along its entire length 2. Ventral margin of coxal plate 4 armed with setae shorter than $1 / 2$ of its length ........ $N$. corpulentus - Ventral margin of coxal plate 4 armed with setae longer than $1 / 2$ of its length .... 3. Uropod 3 exopod bares a well-developed setal fan N. caspius - Uropod 3 exopod lacks setal fan, armed with strong spines N. boltovskoyi

\section{Key to species of Obesogammarus}

1. Posterior margin of pereopods 3-4 with few sparse setae shorter than the underlying segment

- Posterior margin of pereopods 3-4 with numerous setae as long as/longer than the underlying

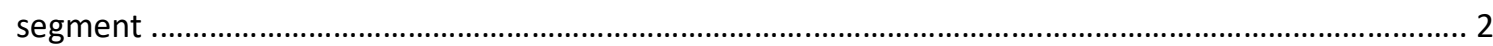

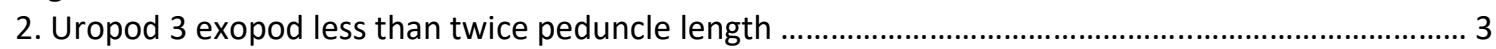

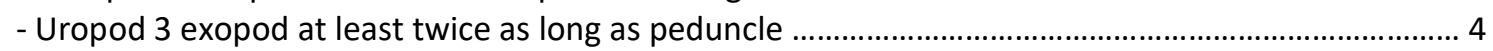

3. Posterior margin of basis of pereopods 5-7 with short setae .............................................. O. olvianus - Posterior margin of basis of pereopods 5-7 with long setae ................................................... O. obesus

4. Coxae 1-2 tapering towards distal end, propodus of gnathopod 2 triangular ................. O. platycheir

- Coxae 1-2 not tapering, propodus of gnathopod 2 roughly rectangular .............................................. 5

5. Medial surface of pereopod 7 basis without setae .............................................................. O. crassus

- Medial surface of pereopod 7 basis armed with clusters of setae .................................................... 6

6. Urosomites with dorsal elevations ................................................................................ . acuminatus

- Urosomites without dorsal elevations ..................................................................................... O. boeoticus

\section{Key to species of Onisimus}

1. Antenna 1 peduncle article 1 longer than head, accessory flagellum 6-segmented, postero-ventral corner of $3^{\text {rd }}$ epimere almost straight O. platyceras 2. Antenna 1 peduncle article 1 shorter than head, accessory flagellum 4-segmented, postero-ventral corner of $3^{\text {rd }}$ epimere sharp . O. caspius

\section{Key to species of Paraniphargoides}

1. Uropod 3 exopod without terminal article, plumose setae absent P. derzhavini

- Uropod 3 exopod with minute terminal article, plumose setae present P. motasi

\section{Key to species of Pontogammarus}

1. Uropod 3 endopod reaches half the length of the exopod $1^{\text {st }}$ article

- Uropod 3 endopod shorter than half the length of the exopod $1^{\text {st }}$ article ............................................ 4

2. Dactylus nail of pereopods 5-7 hook-like ................................................................................. P. sarsi

- Dactylus nail of pereopods 5-7 straight 3

3. Mandibular palp very large, plumose D-setae present, last article of antenna 2 bares continuous setal fan P. maeoticus - Mandibular palp normal, D-setae absent, last article of antenna 2 bares several setal clusters P. weidemanni 
- Urosome flat

5. Dorsal elevations tall, pillar-like P. setosus

- Dorsal elevations low, hump like

6. Urosomite 1 armed with a crown of spines

P. robustoides

- Urosomite 1 armed with setae only

P. aestuarius

7. Uropod 3 exopod $2^{\text {nd }}$ article as long as broad, uropod 2 exopod devoid of spines

P. borceae

- Uropod 3 exopod $2^{\text {nd }}$ article longer than broad, uropod 2 exopod with 1 spine P. abbreviatus

\section{Key to species of Stenogammarus}

11501 1. Uropod 3 reduced, $1^{\text {st }}$ exopod article as long as peduncle S. micrurus

- Uropod 3 not reduced, $1^{\text {st }}$ exopod article longer than peduncle 2

2. Uropod 3 exopod inner margin bare/with 1 long seta ..

- Uropod 3 exopod inner margin with multiple long setae .....

3. Pereopods 6-7 basis medial surface with clusters of setae, basis 6 with long setae on posterior margin, basis 7 with long setae on anterior margin S. compresso-similis - Pereopods 6-7 basis medial surface bare, basis 6 with short setae on posterior margin, basis 7 with short setae on anterior margin .....

S. deminutus

4. Uropod 3 exopod $2^{\text {nd }}$ article shorter than half of $1^{\text {st }}$ article

S. similis

- Uropod 3 exopod $2^{\text {nd }}$ article as long/longer than half of $1^{\text {st }}$ article 5

5. Uropod 3 endopod longer than $2^{\text {nd }}$ exopod article and is $1 / 2$ of $1^{\text {st }}$ article S. compressus - Uropod 3 endopod shorter than $2^{\text {nd }}$ exopod article and is $1 / 31^{\text {st }}$ article S. macrurus

\section{Key to species of Turcogammarus}

\section{Key to species of Yogmelina}

1. Uropod 3 reduced, $1^{\text {st }}$ article of exopod as long as peduncle .

- Uropod 3 not reduced, $1^{\text {st }}$ article of exopod longer than peduncle ................................................... 2
2. Basis of pereopod 7 truncated, abruptly tapering towards the distal edge ....................... Y. ovata*

- Basis of pereopod 7 not truncated, gradually tapering towards the distal edge ................................... 3

3. Coxal plate 1 slightly bent forwards, fringed with short setae .......................................... Y. laeviuscula

- Coxal plate 1 strongly bent forwards fringed with long setae ............................................................ 4

4. Urosomites without setae, epimeral plates 2-3 with short distal setae .................................. Y. pusilla

- Urosomites with setae, epimeral plates 2-3 with long distal setae .......................................... Y. limana 